\title{
MAINTAINING ECONOMIC FREEDOM UNDER THE DEFENSE ACT OF 1950*
}

\author{
DoNaId S. FreY†
}

$\mathrm{F}$

UNDAMENTAL democratic principles are always seriously threatened when a nation launches itself upon a major military program. Thus, the enactment of the Defense Production Act of $195^{\circ}$ raises again the vital question of the extent to which democratic processes can be maintained during periods of military emergency. World War II experiences proved that these principles could be maintained; recent statutes and initial actions thereunder appear to chart a similar course. It appears to be clearly recognized that if these principles are not fully preserved, our country's role as world policeman will become farcical. ${ }^{2}$ This article proposes to discuss three of the basic principles which, it is submitted, must be adhered to if the broad powers conferred in the new Act are to be exercised in a manner compatible with traditional notions of economic liberty and private property. These principles are: (I) All government restrictions on business operations must avoid discrimination and bias. (2) These restrictions must respect sanctity of contract to every possible extent. (3) Voluntary controls must be encouraged as far as possible.

The sole limitation on most of the controls provided for in the new Act is that they be "necessary or appropriate to promote the national defense." 3 The full and fair application of the above principles requires that the expanding meaning of the term "national defense" be thoroughly un-

* Certain parts of this article have appeared in condensed form in Frey, The Concept of "Fairness" in Wartime Economic Controls, 32 Chi. Bar Rec. 7I (1950).

$\uparrow$ Member of the Illinois and New York Bars.

Defense Production Act of I950, H.R. 9176, 8Ist Cong. 2d Sess. (Public L. No. 774, Sept. 8, I950), herein referred to as DPA.

2 Program Committee for the Committee for Economic Development, Economic Policy for Rearmament (Aug. 28, I950); President Truman, Radio Address of Sept. 9, I950; General D. D. Eisenhower, Address Opening Columbia University's Fall Term, Sept. 27, I95०.

3 No property can be requisitioned that is not "needed for the national defense." Special government guarantees of loans and government loans themselves may be made only if "necessary for the national defense." Exemptions may be made from price ceilings and wage stabilization orders if "necessary to promote the national defense." "Effective procedures" shall be made for settlement of labor disputes affecting "national defense." Certain voluntary programs "contributing to the national defense" shall be exempt from the anti-trust laws. If "contrary to the interest of the national defense," controls may be issued without required prior consultation with industry representatives. 
derstood. ${ }^{4}$ The meaning of that term has gradually been extended for the past decade-from the enactment of the Peacetime Conscription Act in September of I940, and the Lend-Lease Act of March, I94I, up through the Economic Cooperation Act of 1948 and the National Defense Act of 1949. Within the past ten years, "national defense" has come to mean

"The term "national defense" is used sixteen times in the Defense Act. It is first used in the closing sentence of the "Declaration of Policy" in such a way as to actually define what is meant by "promoting the national defense." This closing sentence reads: "It is the intention of the Congress that the President shall use the powers conferred by this Act to promote the national defense, by meeting, promptly and effectively, the requirements of military programs in support of our national securty and foreign policy objectives, and by preventing undue strains and dislocations upon wages, and production or distribution of materials for civilian use, within the framework, as far as practicable, of the American system of competitive enter prise."

The "foreign policy objectives" referred to above were defined in the first three sentences of the "Declaration of Policy" as follows:

"It is the policy of the United States to oppose acts of aggression and to promote peace by insuring respect for world law and the peaceful settlement of differences among nations. To that end this Government is pledged to support collective action through the United Nations and through regional arrangements for mutual defense in conformity with the Charter of the United Nations. The United States is determined to develop and maintain whatever military and economic strength is found to be necessary to carry out this purpose."

Elaboration of the phrase, "undue strains and dislocations," (in the first quotation above) and of the phrase, "economic strength" (in the second quotation above) can be found in a long but significant Declaration of Policy to the Price and Wage Stabilization sections of the Act, citing the objectives of the title.

If these two quotations above were not first carefully weighed by a reader, he might be deceived in thinking that the term "national defense" had a more limited scope by reading a formal definition of the term near the middle of the Act as follows: "The powers granted in this title shall not be used or made to operate to compel changes in the business practices, cost practices or methods, or means or aids to distribution, established in any industry, except where such action is affirmatively found by the President to be necessary to prevent circumvention or evasion of any regulation, order, or requirement of this title."

In view of the earlier quoted provisons, the fuller significance is realized of the reference to "the operations and activities ... of any other Government department or agency directly or indirectly and substantially concerned with the national defense," and of the reference to the Mutual Defense Assistance Act of I949.

5 Americans have been stretching the scope of "national defense" for the past decade. The peacetime conscription in September, 1940, was a step in the direction of preparedness for defense to threatening world conditions. The Lend Lease Act in March I94I gave the President power to send arms and supplies to any country whose defense is considered vital to United States defense, whether or not it can pay. This made "aiding the allies" a part of the "defense" program.

Then the World War II laws considerably strengthened the new aspects of "National Defense." The most significant statutes were: Small Business Mobilization Law (I942); National Defense Patents Act (I94I); Atlantic Charter Act (I94I); Defense Amortization Act (I942); Defense Contracts Act (r94I); Defense Housing Act of r942; Defense Property Requisitioning Act (I94I); Excess Profits Tax Act (I940); and the Export-Import Bank Extension Act (I94I).

The direct predecessors of the present Defense Act played their part also. First and Second War Powers Acts (r94I, I942); Emergency Price Control Act of $x_{942}$ (much of the above language of the Declaration of Policy is taken from this Act); Priorities and Allocations Act (I940); and War Mobilization and Reconversion Act of r944.

The United Nations Participation Act of 1945 now appears in retrospect to be laying the groundwork for the statutes that followed in the next few years. United Nations Relief \& Re- 
"international defense" insofar as the United States is determined to support the military defense needs of friendly nations. "National defense" now requires that our nation's economic life be strong and productive and that its people be provided with adequate incentives to increase our productive capacity.

Whether any measure is necessary to the national defense is to be determined by the President. In view of the vastly increasing scope of that term, it might appear that the President has been granted authority to do almost as he wishes with our economic system. However, World War II experiences in the administration of similar controls and the limitations on controls in the new Act, both express and implied, indicate that this is not the case. It is therefore proposed to examine specific controls in order

habilitation Act (I944); Bretton Woods Agreement Act (I944); Atomic Energy Act of r946; the Strategic and Critical Materials Stock Piling Act (1946); National Security Act of I947; Economic Cooperation Act of 1948; Rubber Act of 1948; Mutual Defense Assistance Act of I949 (which stresses the need of military assistance and declares: "The Congress of the United States reaffirms the policy of the United States to achieve international peace and security through the United Nations so that armed force shall not be used except in the common interest.").

Of course, as early as September, $x 943$, the House passed the Fulbright Resolution favoring United States participation in any postwar international peace organization. It was stated by various leaders (e.g., Cordell Hull) that any such organization, to be successful, must be based upon the willingness of the cooperating nations to use force, if necessary, to keep the peace. Then came the conference in April, I945, to set up the United Nations Organization.

New statutes to meet more satisfactorily the drastic home front effects of "national defense" efforts were also taking shape during this decade. Examples are: Armed Forces Damages Settlement Act (1942); Claims Settlement Acts (r944); Contract Settlement Act of 1944; Federal Tort Claims Act (1946); Rent Control Act (I947); Housing \& Rent Act of I948; Renegotiation Act of 1948 ; and Export Control Act of r949. Only recently under this act were lead, zinc, aluminum, and copper placed under strict export-license control.

In addition to the statutes outlined above, various actions by governmental agencies have given depth as well as breadth to the expanded meaning of "national defense." For example, under the National Security Act of 1947 referred to above, the Munitions Board was surveying thousands of firms and entering into "tentative agreements" to produce certain war equipment in the event of all-out mobilization. The Munitions Board also engaged itself in a long and complex process of determining coordinated requirements for thousands of items. 700 highly important items have been given priority by the Munitions Board. The number will finally reach 5,000 .

The Munitions Board considers that the first ingredient of production is plants. 270 are owned by the U.S., 200 are placed in reserve and leased out. With respect to 30,000 , the military is negotiating with management upon production capacity and production schedules agreeable to management.

Simultaneously with planning for increased military production, business is preparing for lower tariffs and higher taxes as a result of our new National Defense program. As to tariffs, it is believed that the increased flow of military orders will remove the threat of injury to United States industries and the flow of cheaper imports may actually help water down the inflationary spiral. As to the tax problems, the recently enacted Revenue Act of $195^{\circ}$ presents the most comprehensive tax changes since the 1942 Revenue Act. The cost of emergency facilities certifed as necessary for "national defense" can be written off over a five-year period. An excess profit tax to "take the profit out of defense production" is also being planned. 
to determine what limitations exist on the broad powers delegated to the President and what policies and practices may not be necessary or appropriate for the national defense.

\section{The Defense Act of I950-Its Provisions}

While substantially all the powers authorized by the Act were exercised in World War II, one important difference in general conditions must be noted at the outset. The present economic problem is unique in that for the first time we must effect a partial mobilization of substantial proportions under conditions of comparatively full employment and nearcapacity operation in many fields. Because half-war is probably psychologically more wearing than all-out military conflict, and because extensive controls may be more difficult to initiate and maintain in such a situation, it is especially important that established democratic processes be observed, and indeed enlarged upon, if possible. A semi-war economy brings simultaneously upon the national scene the problems both of rapid mobilization of industry and manpower and of gradual reconversion when industry and workers must prepare for decreasing military demands. ${ }^{6}$

\section{A. TITLE I-PRIORITY AND ALLOCATION POWERS}

Section Ior of the new Act authorizes the President to assign priorities to, and require acceptance and performance of, orders which he deems necessary or appropriate to promote the national defense. ${ }^{7}$ The power to

\footnotetext{
${ }^{6}$ See Hettinger, Business Planning in Half War, Management Review, p. 434 (Aug. I950). There were even some evidences all during World War II of the desire to begin rebuilding the civilian economy. Of course, plans had to be hatched early to cushion the economic shock of the close of the war. For example, as early as December, 1943, the WPB had okayed the manufacture of 2 million electric irons for civilians.

7 Section ror reads as follows: "The President is hereby authorized (x) to require that performance under contracts or orders (other than contracts of employment) which he deems necessary or appropriate to promote the national defense shall take priority over performance under any other contract or order, and, for the purpose of assuring such priority, to require acceptance and performance of such contracts or orders in preference to other contracts or orders by any person he finds to be capable of their performance, and (2) to allocate materials and facilities in such manner, upon such conditions, and to such extent as he shall deem necessary or appropriate to promote the national defense."

The allocation provision above is almost identical with the provision in Title III of the Second War Powers Act of 1942. For example, it permits the President to stop or reduce production of any item, direct use of particular materials for specified purposes, allocate productive facilities, transportation facilities, power and fuels, ration consumer goods at the retail level, and restrict or prohibit "less essential" industries. For example, in World War II, the "conservation orders" in the textile field resulted in skirts and shirt-tails being shorter, pants having no cuffs and shorts having no pockets. In the petroleum field, all pleasure driving was banned in the east and a " 72 Order" for gas stations was made nation wide.

Similar priority power was already contained in the Selective Service Act of I948, but with one important difference. Such power could be exercised only for procurement of items authorized by Congress "exclusively" for use of the armed forces or the Atomic Energy Commission.
} 
allocate materials and facilities is granted subject to the same limitation. ${ }^{8}$ The Second War Powers Act of I942 expressly required the finding of a present "shortage" before allocation controls could be imposed. Although there is no such requirement in the new statute, it seems clearly to be implied in view of statements to that effect in the Declaration of Policy and in congressional committee hearings. ${ }^{9}$ The elimination of this requirement in the present Act was intended to permit immediate imposition of controls, without question of legality, on substitutes for scarce material which had already been placed under control. Such substitutes might otherwise be quickly dissipated.

Despite the broad priority and allocation powers conferred in the World War II statute, procedures were developed which had as their objective the elimination of all arbitrary and unnecessary requirements. These procedures must therefore be considered in appraising the new Defense Act.

As of this writing, the National Production Authority (a separate agency in the Commerce Department to which most of these priority and allocation powers have been delegated) has issued two important regulations. ${ }^{10}$ NPA I, which represents the first exercise of the allocation power, requires that all firms reduce to a "practical minimum working inven"tory" their supplies of certain designated scarce materials such as burlap and zinc. This regulation's test of a proper inventory as being a supply large enough to meet current production schedules permits the exercise in good faith of individual discretion and business judgment. NPA 2 assigns a single priority rating for all "defense orders"; it permits military procurement officers and the Atomic Energy Commission to require that their orders be given priority over others.

The significance of this second order can be appreciated only in the light of World War II experiences in assigning priorities. Under the initial priority system in World War II, the government assigned priorities to individual transactions by issuing preference-rating certificates. Standards were established within the war agencies as to the essentiality of various commercial operations, and when an individual falling within a particular essential category requested a priority and indicated to the $\mathrm{WPB}^{\circ}$ that the priority was necessary to obtain delivery of a certain item, a rating

\footnotetext{
${ }^{8}$ An unsuccessful attempt was made in Congress to limit the priority order to items which Congress had authorized exclusively for use of the armed forces or the Atomic Energy Commission. See I2 N.A.M. Law Digest, No. 4, at 65, 66 (Sept., 1950).

9 Ibid.

${ }^{\circ}$ NPA Reg. I (Sept. I8, I950), I5 Fed. Register 6253 (I950); NPA Reg. 2 (Oct. 3, 1950), I5 Fed. Register 6632 (I950).
} 
certificate (PD-IA) would be issued to him. Over three million of such certificates were issued from January, I94I to May 3 I, I944. ${ }^{\mathrm{II}}$

It soon became evident that much of the time and paper work involved in this system could be eliminated by issuing regulations assigning blanket priority ratings to certain industries. The members of such industries were instructed to certify on their purchase orders that they were entitled to this rating pursuant to the government regulation. Under the initial system, the manufacturer of electric cranes, for example, was required to obtain separate priority certificates for each of the many thousands of items which he procured each month. Under the blanket system of priority assignment, however, he had to obtain but one such order.

It further became evident in World War II that even a single priority rating (as now existing in NPA Regulation 2) was unsatisfactory in obtaining very scarce materials, since producers of such materials found themselves unable to fill all of their rated orders. This led to the establishment of classes of ratings which set forth degrees of preference; a constant battle on the part of each purchaser trying to win a higher type rating for himself was the result. (The first deviation by NPA from a singleclass rating for exclusive use of the military and AEC is already evident in the issuance of an order requiring steel producers to accept "certified orders" from firms engaged in building freight cars. ${ }^{12}$ The commercialairplane building industry is currently demanding "across-the-board" priorities for all the supplies it needs.)

Although the quantity of scarce material available for less essential industries was also reduced by other regulations during World War II, in the distribution and allocation of very scarce metals the priority system had to be abandoned in the middle of the war. The aggregate quantity of rated orders that had to be filled could not be brought into line with the

Ir O'Brian and Fleischmann, The WPB Administrative Policies and Procedures, $\mathrm{I}_{3}$ Geo. Wash. L. Rev. I, 28 (I944); see report in Oct. 3, I950 issue of New York Journal of Commerce, quoting Donald Nelson in reciting troubles of priority system during World War II.

A simple statute provided the basis of World War II's whole system of industrial government. Second War Powers Act, 56 Stat. I76, I77 (1942); 50 U.S.C.A. $\$ 622$ (App., 1944). It entrusted to the President probably the most sweeping grant of authority in our history up to that date. The new Defense Act probably gives slightly wider powers, but what is more important is that it rests upon the experience of many democratic safeguards developed in recent years. At its height in I944, the industrial-government system was regulating weekly more than one hundred thousand transactions of the most diverse nature and controlling the activities of more than 250,000 manufacturers, wholesalers and retailers. For index to all regulations during World War II, see Tabulation of Documents, 32 Code Fed. Reg. 9299, 9327 (Cum. Supp., I944).

${ }^{12}$ NPA Order M-I (Supp., Oct. 26, I950), I5 Fed. Register 7208-og (1950). 
available supply. A Controlled Materials Plan (CMP) was developed whereby requirements of steel, aluminum and copper for each military and essential civilian project were determined months in advance of specific delivery dates. Contractors working on these projects were assigned their share of these controlled materials and were granted the authority necessary to obtain other supplies and facilities to use with these materials at the designated times. ${ }^{13}$

The demand and supply at last became fairly synchronized so that there were no longer cases like that where several hundred thousand tons of steel plate became piled up in a shipyard long before the yard was completed and ship construction was ready to begin.

NPA Regulation 2 embodies practically all of the careful rules developed during World War II to handle the disposition of priority orders with the least possible interruption of ordinary operations and with the utmost fairness. ${ }^{x}$ For example, the rated order need not be accepted if the purchaser is unwilling to meet the supplier's "regularly established prices and terms of sale." By permitting the supplier to fix his own terms, the question of just compensation under the 5 th Amendment to the federal Constitution is eliminated. In other words, such priority order could not be deemed to be a confiscation of property. However, the prized asset of the American business man to choose his own customer had to be restricted for reasons of expediency. Another example of a rule embodied in NPA Regulation 2, which is based upon World War II experience is the requirement that all rated orders specify delivery dates, which in no case are to be earlier than the dates by which the materials are needed. ${ }^{\text {t5 }}$

NPA has taken a novel step in requiring that rated orders for steel be spread equitably over the whole industry. ${ }^{16}$ No producer need accept more than a certain percentage of rated orders. Indicative of the complexities that quickly develop around any exercise of the allocation power are recent complaints in regard to this step. It is being contended that suppliers who had previously established voluntary allocations of steel are now reducing their allotments to firms submitting priority orders. Moreover, it is claimed that governmental demands for increased steel production by means of these orders are intended to socialize the steel industry.

13 O'Brian and Fleischmann, op. cit. supra note II, at 35 .

${ }^{14}$ NPA Reg. 2 (October 3, I950), I5 Fed. Register 6632 (1950); O'Brian \& Fleischmann, op. cit. supra note II, at 33 .

${ }^{55}$ NPA Reg. 2, § Ix.x5 (October 3, 1950), I5 Fed. Register 6632, 6635 (1950).

${ }^{16}$ NPA Order M-I (Oct. I2, I950), I5 Fed. Register 69II, 6914-I5 (1950). 


\section{B. TITLE II-REQUISITIONING POWERS}

Section 202 of the Defense Act authorizes the President to requisition certain property which is needed for the national defense, provided "that such need is immediate and impending, and such as will not admit of delay or resort to any other source of supply and that all other means [such as bidding on the open market] upon fair and reasonable terms have been exhausted."

This title further provides that the President shall pay "just compensation" for the requisitioned property. What constitutes "just compensation" shall be determined promptly by the President. If the owner disagrees with the amount determined, 75 per cent of such amount is to be promptly paid to him. (Only 50 per cent of this amount was paid in World War II.) The owner may then bring suit to have the final amount determined. When the requisitioned property is no longer needed, an effort must be made to return the property to the original owner upon payment of the "fair value" thereof. ${ }^{17}$

The requisitioning power applies to all types of "materials or facilities." The word "materials," wherever used in the Act, is defined as including "raw materials, articles, commodities, products, supplies, components, technical information, and processes," whereas the word "facilities" is limited only by exclusion. ${ }^{18}$ Facilities, by definition, shall not include farms, churches, or other places of worship, or private dwelling houses. ${ }^{19}$ Presumably, therefore, all other property, real or personal, would be subject to requisition if the power were exercised within the broad definition of "national defense" and the stated conditions in the Act were observed. Thus the combined authority to impose priorities and allocations and to requisition property gives the President almost complete power over the productive economy of the nation.

The requisitioning power is among the most summary and drastic of the Defense Act powers, making the United States in effect one huge stockpile. The conditions precedent to the exercise of this power set forth above provide some safeguards. Further curbs on arbitrary action are indicated in the Executive Order redelegating the requisitioning power to the agencies empowered to exercise the priority and allocation powers described above. ${ }^{20}$ Most of such authority goes to NPA. Overall program-

${ }^{27}$ DPA $\& 201$ (b), (c). $\quad{ }^{88}$ DPA \& 702 (b). $\quad{ }^{29}$ DPA $\S 702$ (c).

${ }^{20}$ Power over food has been given to the Agriculture Department; over fuel and power to the Interior Department; over transport and storage facilities to the ICC. Exec. Order No. I0I6I (Sept. 9, I950), I5 Fed. Register 6I05 (1950). 
ming is vested in the Chairman of the National Security Resources Board. The pattern likely to be followed, therefore, will be that pursued in World War II where uniform procedures were followed by all of the agencies to which the requisitioning power had been delegated. The WPB (in the position of the NSRB today) required all requisitioning proposals to be submitted to it for review in conformance with general supply and allocation policies.

Under the Requisitioning Act of $x 940{ }^{2 \mathrm{I}}$ the government could only requisition critical materials and equipment which had been destined for export but for which exportation had been denied. However, the Requisitioning Act of $\mathrm{x} 94 \mathrm{I}^{22}$ allowed requisitioning of "any material . . needed for the defense of the United States." The I950 version is substantially the same except for increasing the payment from 50 per cent to 75 per cent as noted above. No complaints relating to arbitrary or unnecessary action arose from the administration of the I94I Act.

\section{TITLE MI-DEFENSE FINANCING POWERS}

Section zor authorizes the President to reinstate a guaranty loan program similar to the V-loan program operated by the Federal Reserve System during World War II. Under this program the President may authorize agencies engaged in procurement for national defense to guarantee any public or private financing institution against loss on any commitment made for the purpose of financing "national defense" contractors, subcontractors, or any other persons connected with the performance of defense contracts. ${ }^{23}$ By executive order, the President has already named the Departments of the Army, Navy, Air Force, Commerce and Agriculture and the General Services Administration as "guaranteeing agencies"24 to prescribe regulations setting up maximum limits and rates of interest; the same executive order has delegated defense financing powers to the Board of Governors of the Federal Reserve System, as required by the Act.

It appears that the initiative under this power will come from the "guaranteeing agencies" who are instructed to "develop and promote measures for the expansion of productive capacity ... necessary for the national defense." Established industries may be expected to protest moves for increasing their productive capacity, questioning the long range economic effect of such moves, the necessity of the expense involved. Protection

\footnotetext{
${ }^{2 x} 54$ Stat. Iogo (1940), 50 U.S.C.A. \& 7 II (1944).

${ }^{22} 55$ Stat. 742 (I94r), 50 U.S.C.A. $\$ 721$ (r944).

23 DPA § 3 or.

${ }^{24}$ DPA \& 3 or.
} 
against governmental actions that are arbitrary or biased, and actions that seriously affect private contracts or further restrict voluntary measures, can be obtained only by setting up careful standards covering the exercise of the defense financing powers and by full adherence to these standards in actual practice. The first regulation ${ }^{25}$ of the Federal Reserve System covering these powers promises that it "will follow . . . procedures developed from experience obtained in the administration on the V-loan and T-loan programs during World War II." However, responsibility is placed with the certifying officer of the guaranteeing agency as to whether a proposed loan is "necessary to expedite production and deliveries or services ... for the national defense." Perhaps the chief curb on arbitrary actions of the certifying officers is the right of persons to protest to the "watchdog congressional committee" provided for under the Act and to be discussed later.

The same may be said for Section 302 of the Act which empowers the President to make loans to private business enterprises for the same purposes. The RFC will make these loans, but only upon certificates from the appropriate government agency in respect to the particular material or facility involved. ${ }^{26}$

In this same connection, a five-year amortization of essential defense plant expansion is permitted under a provision of the I950 Revenue Act.7 The Chairman of the NSRB is named as the certifying authority for this accelerated amortization procedure. The regulation issued by the $\mathrm{NSRB}^{28}$ attempts to spell out the "criteria for determination of (defense) necessity" of any proposed plant expansion. These criteria included the relation of such expansion to national defense (broadly defined), "the economic usefulness of the facility for other than defense purposes after five years," "promotion of competitive enterprise," and "opportunity for participation by small business."

This title also includes a provision (Section 303) authorizing the President to purchase materials for government use or resale in cases where found necessary to encourage "exploration, development and mining" of "critical and strategic items" (evidently in cases where insufficient incentives for producers exist). ${ }^{29}$ Congress has carefully prevented this pur(1950).

\footnotetext{
${ }^{25}$ Reg. V, Federal Reserve System $\$ 223.2$ (Oct. 2, I950), I5 Fed. Register 6630, 663I

${ }^{26} \mathrm{DPA} \S 303$.

${ }^{27} \S \mathrm{r} 246$ [§ 216 Pub. L. 8I4, 8rst Cong. 2d Sess. (1950)].

${ }^{28}$ NPA Order M-5 (Oct. 27, I950), I5 Fed. Register 7264 (I950).

${ }^{29}$ I2 N.A.M. Law Digest, No. 4, at 65, 68 (Sept., I950).
} 
chasing power from being used as a mere method of subsidizing agricultural commodities (e.g., Brannan Plan) by first prohibiting purchases of these commodities except for resale for industrial uses or stockpiling, and second, by requiring that the commodities be sold for not less than the higher of the current market price or the minimum sales prices established by the Commodity Credit Corporation. This power has been redelegated to the Administrator of General Services.

All of the above-described defense financing powers existed during World War $I^{30}$ in substantially the same form. The V-loan program was self-supporting. ${ }^{3 \mathrm{x}}$

\section{TITLE IV-PRICE AND WAGE-STABILIZATION POWERS}

Section 402 of this title ${ }^{32}$ authorizes the President to establish ceilings on prices "of any material or service, and at the same time [he] shall issue regulations and orders stabilizing wages, salaries, and other compensation." Unlike the procedure in World War II, wage stabilization must be simultaneously effected whenever a price control is issued. This is believed to be a great advance, not only in fuller recognition of sound economics, since prices cannot be frozen without holding labor costs to an equal level, but in fair treatment to all segments of the economy.

However, it must be pointed out immediately that "stabilizing wages" does not mean "freezing" wages. It would seem that wage increases may be permitted after a stabilizing order if they do not "require an increase in the price ceiling or impose hardships or inequities on sellers operating under the price ceiling." ${ }^{33}$ It is clear that this provision requires the President to decide what is a fair margin of profit, for otherwise there would be no means by which to decide whether a wage rise would impose a hardship on a seller operating under a ceiling. While this provision has been criticized it should be noted that this was also done in World War II, and sellers were generally successful in maintaining their customary profit margins. These determinations are to be made by the President, who has delegated all of his functions under this title to the Administrator of a new and independent agency to be known as the Economic Stabilization Agency. ${ }^{34}$ Under the Administrator, there shall be two divisions, one headed I949).

${ }^{30}$ Second War Powers Act, 56 Stat. I77 (I942), as amended 50 U.S.C.A. $\$ 633$ (Supp.,

${ }^{3 x}$ H.R. Rep. No. 2759, 8ist Cong. 2d Sess. 8 (1950).

${ }^{32} \mathrm{DPA} \S 402$ (b) (2).

${ }_{33} \mathrm{DPA} \S 402$ (b) (2).

34 Exec. Order No. Ior6I, § 401 (Sept. 9, 1950), 15 Fed. Register 6105, 6106 (I950). 
by a Director of Price Stabilization (corresponding to OPA in World War II) and the other headed by a Chairman of the Wage Stabilization Board (corresponding to the War Labor Board).

Another advance over World War II procedures is the provision ${ }^{35}$ that no price and wage stabilization powers may be exercised over a subject unless "voluntary action by business, agriculture, labor and consumers" fails to attain the same end. Some lawyers are claiming that no standards are set forth in the Act as to when "failure" of voluntary action has taken place and that the President can proceed at any time to exercise these controls. It appears to this writer that "failure" refers to the situation which exists when the objectives of the title are not currently being met. How long such failure may be allowed to exist must be left to executive judgment to be questioned only by Congress itself. ${ }^{36}$

In addition to the requirement that "voluntary action" be tried first, the title prohibits imposing a price ceiling except where the President finds that " $(i)$ the price of the material or service has risen or threatens to rise unreasonably above the price prevailing during the period from May 24, I950 to June 24, I950, (ii) such price increase will materially affect the cost of living or the national defense, (iii) the imposition of such ceiling is necessary to effectuate the purposes of this Act, (iv) it is practicable and feasible to impose such ceiling, and (v) such ceiling will be generally fair and equitable to sellers and buyers of such material or service and to sellers and buyers of related or competitive materials and services." ${ }_{37}$

All five of the above conditions must be present. What is an "unreason-

${ }^{35}$ DPA $\S 402$ (b) (2).

${ }^{36}$ The objectives which voluntary action should try to accomplish are enumerated in great detail and can be grouped as follows:

To prevent:

(r) Inflation (preserve value of currency)

(2) Dissipation of defense appropriations

(3) Profiteering, manipulation, speculation

(4) Hoarding

(5) Labor disputes (other economic disturbances affecting mobilization and morale)

(6) Dissipation of individual savings (loss of future purchasing power)

(7) Future collapse of values.

To achieve:

(r) Stabilize cost of living for workers, consumers

(2) Stabilize cost of production for farmers, businessmen

(3) Protection of fixed limited income groups

(4) Reasonable balance between purchasing power and supply.

To maintain and further, so far as is practical:

(I) American system of competitive enterprise (including small business)

(2) Sound agricultural policies

(3) Sound working relations (including collective bargaining).

37 DPA $\& 402$ (b) (2). 
able rise" above May 24-June 24, I950 prices is a question for executive decision, except that such rise must be one that "materially affects the cost of living or the national defense" and the price regulation itself meets the other conditions stated above. While it has been observed that these conditions are so "abstract as to make rational analysis almost impossible," it must be noted that the standards are slightly more precise than they were in the World War II legislation. "The fair and equitable to sellers" test apparently is intended to protect a producer whose sources of supply are not price-controlled but whose own prices are controlled.

Next to the priority and allocation powers, the price and wage stabilization powers constitute the-most severe challenge to the continued exercise of the democratic principles which this paper is exploring. The Economic Stabilizer announced recently that the new Defense Act controls may have to endure for many years and in such a way that our "economy at the end of that time [be] stable, productive and free." ${ }^{38}$

\section{E. TITLE V-LABOR DISPUTE SETTLEMENT POWERS}

Sections $50 \mathrm{O}-3$ " 3 of this title provide for setting up "effective procedures for the settlement of labor disputes affecting national defense." These procedures are to be agreed upon through voluntary conferences (initiated by the President) between management, labor and public members. Because such procedures must be in line with the stabilization policies of the Act, the President has appropriately delegated his powers under this title to the Economic Stabilizer described in the section above. ${ }^{4^{\circ}}$

Although no permanent body similar to the War Labor Board of $194^{4 \mathrm{II}}$ seems specifically authorized by this title, the conference committee's report states its intention to be that the President be thereby authorized to establish such a board, but not before the voluntary conferences have been held reaching some agreement on procedures.

Like the previous titles, this title specifically recognizes the principle of voluntary action by placing "primary reliance" upon the parties to any labor dispute to make every effort through "negotiation and collective bargaining and the full use of mediation and conciliation facilities," and upon the above mentioned provision for "voluntary conferences." The

${ }^{38}$ N.Y. Journal of Commerce, p. I, col. 7 (Nov. x, 1950).

39 DPA.

$4^{\circ}$ Exec. Order No. ror6r, § 404 (Sept. 9, I950), I5 Fed. Register 6105, 6I06 (I950).

${ }_{41}$ I2 N.A.M. Law Digest, No. 4, at 65, $7 x$ (Sept., I950); see interesting review of similar labor-management conferences in World Wars I and II, N.Y. Journal of Commerce (Sept. I5, I950). 
sanctity of private contracts is also recognized to some extent here by the provision that "no action may be taken inconsistent with the provisions of the Labor Management Relations Act of I947." Safeguards against arbitrary actions are also provided by the review of all such actions under this title by the President and Congress.

\section{F. TITLE VI-CREDIT CONTROI POWERS}

Section 6or of this title authorizes the exercise of consumer credit controls in line with the provisions of a World War II Executive Order (No. 8843, Aug. 9, I94I). This power is specifically assigned to the Federal Reserve Board, as was done in World War II. The Board has promptly proceeded to issue a regulation ${ }^{42}$ establishing minimum down payments and maximum maturities on installment sales of certain designated articles (for example, autos, furniture, television sets, and residential repairs). Currently, fewer items have been designated, and longer maturities and lower down payments have been required, than in the last war.

Other appropriate controls to restrict consumer credit are authorized by this provision with a view to reducing the aggregate consumer demand for scarce items so that the prices will not increase, and the materials needed for military projects will not be drawn into civilian channels. The Economic Stabilizer has stated that credit and allocation control are of far greater importance in fighting inflation and promoting defense efforts than wage and stabilization controls. ${ }^{43}$ For example, he likens the price ceilings to trying to "tie the lid on a boiling tea kettle." The lid will eventually "blow off" unless the "flame is turned down" (heavier taxes, credit and buying restricted) or "the kettle moved" (production materials allocated elsewhere).

Section 602 of this title authorizes the President to regulate all kinds of construction credit. This power has also been delegated to the Federal Reserve Board, with instruction, however, to obtain the "concurrency" of the Housing and Home Finance Administrator regarding residential property. The Board has already issued a regulation covering maximum loan or credit values, minimum down payments in cash or property, and so forth, for construction begun since August 3, I950.44

This regulation has met with violent protests from the mortgage and building industries who see their volume of present operations being sub-

\footnotetext{
${ }^{42}$ Reg. W, Fed. Reserve System (Oct. 2, r950), I5 Fed. Register 6630 (1950).

${ }^{43}$ N.Y. Journal of Commerce, p. I, col. 7 (Nov. I, x950).

${ }_{44}$ Reg. X, Fed. Reserve System (Oct. I2, I950), I5 Fed. Register 68I7 (I950).
} 
stantially reduced..$^{45}$ Labor representatives have said that the controls discriminate against the poor man, preventing him from buying homes. The Senate Committee report urged that special consideration in issuing regulations be given to situations where builders "might suffer irreparable hardship under an unduly harsh exercise of the real estate credit controls." The Act seems to authorize the President to curtail or totally to suspend credit for any particular type of construction if found necessary to channel all materials and labor into construction of defense plants and similar facilities. In supervising such controls, the President is required to consider, among other factors: (a) the trend of such credit, (b) the effect upon purchasing power and realty demand, (c) the need of sound credit, and (d) the need for increased defense production.

World War II legislation did not provide the President with similar construction credit powers. Types of nonessential construction were substantially controlled by a WPB "Limitation Order" which included provisions for "hardship cases" and curbs on arbitrary actions similar to those discussed above..$^{6}$

\section{G. MANPOWER CONTROLS}

The manpower problems in World War II did not become serious until late in I942, when the large pool of unemployed became exhausted. For example, the army continued to draft $\mathrm{I}, 000$ men per month from the Kaiser shipyards, which at the same time had been ordered to speed up production. Many war plant employers admitted that they hired three men whenever they needed one.

Although it is not a serious omission, the Defense Act is silent on manpower controls. A critical shortage of manpower may soon exist under the National Defense Program because of the current high rate of employment and the expanding demands of the army, navy, and air force. Probably for these reasons, and in spite of the Defense Act's silence, the President, in the same order in which he delegated the several specific responsibilities of the Defense Act to various agencies, ordered the Secretary of Labor to "meet the labor needs of defense industries and essential civilian employment." ${ }_{47}$ The Labor Secretary has proceeded to set up an Office of Defense Manpower, patterned after the World War II War Manpower Commission. Manpower planning includes manpower priorities, occupa-

45 I2 N.A.M. Law Digest, No. 4, at 65, 76, 77 (Sept., I950).

${ }_{4}^{6} \mathrm{O}^{\prime}$ Brian and Fleischmann, op. cit. supra note $x \mathrm{I}$, at 2.

47 DPA § 6or; see also Dept. of Labor's General Order No. 48, Oct. 3, r950; see statement of "Essential Activities and Critical Occupations," Aug. 20, 1950. 
tional deferments, timely adjustments of labor disputes, relaxation of state and federal laws when necessary in particular cases, and channeling of workers into essential production.

\section{H. LEGALITY OF ABOVE GOVERNMENTAL ECONOMIC POWERS}

Whether the standards fixed by Congress in this Act are sufficiently definite to validate the general delegation of authority to the President would be a troublesome question if World War II decisions did not exist. ${ }^{8}$ It has now become evident that the changing supply situations and rapid developments in military weapons justify general delegation of authority.

In World War II, Congress believed that the constantly changing and emergency nature of the defense efforts made it feasible for the President to exercise his priority and allocation powers through any agencies he might care to create. Under the present National Defense Program, about which Congress is thinking in terms of longer range, a desire to see that the established agencies handle the power is evident. However, the President is given authority to establish new agencies ${ }^{49}$ and he is specifically required to establish a separate agency to administer the price and wage stabilization controls when price and wage controls are generally imposed over a substantial portion of the national economy. The President has reflected Congress' present intention in his first Executive Order by assigning the responsibilities under the Defense Act among the established agencies of the Executive Department.

\section{Avomance of Discrinination and Bias}

\section{A. JUSTIFIABLE DISCRIMUNATION}

The only difference in the judicial and moral connotation of fairness during time of peace and time of war is that in the latter military demands justify a favored assistance to essential persons and plants..$^{\circ 0}$ An airplane manufacturer is favored over a manufacturer of juke boxes in allocating materials, making defense loans and granting relief from price ceilings. This is deemed fair and not unjustly discriminatory because it is absolutely necessary to defense efforts. Nor is it considered discrimina-

\footnotetext{
$4^{8}$ Steuart \& Bros. v. Bowles, 322 U.S. 398 (I944); Bowles v. Willingham, 32 I U.S. 503 (1943); Yakus v. United States, 32I U.S. 4I4 (1943); United States v. Curtiss-Wright Corp., 299 U.S. 304 (I936); Hampton \& Co. v. United States, 276 U.S. 394 (xg27).

49 DPA $\$ 403$.

so O'Brian and Fleischmann, op. cit. supra note $r x$, at 20 . Thus in $\S 402$ (c), the President is required to give due consideration to the national effort to achieve maximum production in furtherance of the objectives of this Act. A specific example of this in World War II was that a special premium was allowed in the price-ceiling order covering textile bags badly needed for flour export.
} 
, tory in time of emergency to allow higher profit margins for the production of essential items; unequal margins are regarded as justifiable since they induce greater production.

Section 402 (f) of the new Defense Act authorizes the President to provide exemptions from price and wage ceilings for any materials or services, or transactions therein, or "types of employment" where it is found: (I) that such exemption is necessary to promote the national defense, or (2) that the application of such ceilings, or stabilization of such types of employment, is unnecessary to effectuate the purposes of the Act. According to the report of the Senate Committee, ${ }^{\text {sx }}$ the purpose of this subsection "is to permit minor adjustments of inequalities in order to effectuate the purposes of the bill and is not intended to permit the elimination of price or wage controls on an arbitrary basis in any area of controls."

This section is built on the precedent of World War II actions when the OPA exempted various scarce metals and chemicals from the ordinary price control provisions..$^{52}$ The OPA's actions in this respect were not criticized, for all recognized the extreme importance of inducing the greatest possible production of these items. This section also relates to the provision of the Defense Act discussed earlier ${ }^{53}$ authorizing the government to purchase certain "strategic materials" in such ways as to provide greater incentives to producers.

As before, the concept of fairness must be applied continually to every government control in order to avoid discrimination between all persons and firms in each category of essentiality. Fairness in classifying firms according to essentiality becomes itself a major problem. ${ }^{54}$ For example, too great a degree of discrimination in favor of the military and against civilian services has always been a threat. NPA's initial rating system ${ }^{55}$ may be used as a grab bag by the armed services; there is nothing to prevent the defense department from earmarking materials for military orders too far in advance, thereby reducing civilian production long before such reduction would otherwise be necessary.

"If war should come again," Donald Nelson once warned, ${ }^{66}$ "I cannot

${ }^{5 x}$ Senate Committee on Banking and Currency, Sen. Rep. No. 2250, 8Ist Cong. 2d Sess. 38 ( 1950 ).

52 Ibid.

53 DPA $\& 303$ (a).

54 Authorities cited notes 20 and 47 supra; also see Chicago Journal of Commerce, p. I (November 13, I950).

55 Authorities cited note ro supra.

${ }^{6} \mathrm{New}$ York Journal of Commerce, p. 4, col. I-2 (Oct. 3, I950). 
urge too strongly that at least one or two civilians who are charged with industrial production should be vouchsafed all of the Army's requirements, not after they have been formulated but during the process of formulation. This, I maintain, is one of the most indisputable imperatives concerning the relationship between civilian and military agencies."

To some extent the architects of the present National Defense Program have heeded this warning in placing a civilian, the Chairman of the National Security Resources Board, as the top coordinator of the whole program. In addition, the Council of Economic Advisers shall "furnish guides to the agencies ... in promoting balance between defense and civilian needs." 57

Also, to see that the justifiably favored orders of the military are not borne unequally by producers, NPA recently issued Order M-I which limits the percentage of rated orders for certain types of steel which a producer is required to accept..$^{8}$ This order attempts to provide an equitable distribution of priority orders among all steel producers in order to maximize production and to reduce disruption of normal distribution to a minimum. One section of the order provides that if any person having a military contract is unable to place a rated order due to these percentage limitations, the NPA will arrange to assist such persons in locating other sources of supply. It is believed that this order will establish a pattern for other orders covering scarce materials soon to be issued.

One method of avoiding discrimination during World War II was the practice formulated by the WPB of insisting that all orders and regulations contain a statement of the standards to be followed in their administration. For example, instead of requiring each individual producer of farm machinery to apply for a quota of production, the order stated on its face that each producer was permitted to manufacture a specified percentage of his production in a selected base period. In this way, discrimination and secret preferred treatment were avoided. When the standards could not be fully set forth in the order because of inability to formulate them with sufficient definiteness, the administrative record which was prepared and filed in connection with the issuance of every order was required to describe in considerable detail the problem which the order was designed to solve, the general purpose of the control and the methods and policies of administration which would be followed. No order was issued

57 Authority cited note 20 supra, $\$ 803$.

${ }^{8}$ NPA Order M-I (Oct. 12, I950), 15 Fed. Register 691I'(1950). 
without such a written justification. ${ }^{59}$ This World War II practice has now become the law. ${ }^{60}$

\section{B. SPECIAI HARDSHIPS}

In addition to the category of discriminations that are justifiable for military purposes, the enforcement of broad regulations may cause special hardship cases to arise. The Act anticipates and provides specifically for some of these situations. In addition, provision is made in more general terms for meeting those situations which can not be specifically anticipated. An example of the first case is a provision which places a floor on prices for agricultural commodities and further provides that processors of these commodities must be allowed a "generally fair and equitable margin." This provision relates, for example, to cotton mills which may have their own manufacturing margins squeezed too tightly should the price of raw cotton rise considerably without proportionate changes in the ceiling price on cotton cloth.

An example of the second type of case is a provision with respect to price ceilings. This requires that the President "shall make appropriate provision to prevent hardships and inequities to sellers who have bona fide contracts in effect on the date of issuance of any such regulation or order for future delivery of materials in which seasonal demands or normal business practices require contracts for future delivery." ${ }^{\prime 2}$ While some observers have stated that this provision protects cotton-mill operators who must buy raw cotton at higher prices in order to perform contracts already made for future delivery, this provision would seem to protect any seller who does business in this way.

Another example of the second type of case is a provision which requires the President to give consideration to the following factors in adjusting ceilings: "[s]peculative fluctuations, general increases or decreases in cost of production, distribution, and transportation, and general increases or decreases in profits earned by sellers." ${ }^{\prime 3}$

so O'Brian and Fleischmann, op. cit. supra note Ir, at 39-40.

${ }^{60} \mathrm{DPA} \S 4^{\circ} 2$; what some observers claim is an unjustifiable discrimination is that provision $\left[\S 4^{\circ} 2\right.$ (d) (2)] which provides that no wage, salary, or other compensation "shall be stabilized at less than that paid during the period from May 24, $195^{\circ}$ to June 24 , 1950, inclusive." No similar limitation is prescribed with respect to prices for the President need only "consider" the above period in fixing price ceilings. Consequently, it will be possible for the President to fix, or "roll-back" price ceilings as of one base period and stabilize wages as of another.

6r DPA $\S 402$ (d) (3).

${ }_{62}$ DPA $\S 402$ (d) (I).

${ }_{63}$ DPA \& $4^{\circ 2}$ (c). 
Examples of "special hardship" claims under the allocation controls are: (I) claims that on basis of insufficient amount of raw material allotted to a claimant firm it cannot economically operate its plant a full work week and must therefore start discharging employees; (2) claims that a particular base period named in an allocation order-granting each firm a percentage of this base period's use by such firm-is unfair for this particular claimant because he would not be in business during this period or had abnormally low business during that period; (3) claims that new equipment at great expense was installed just prior to the allocation order and now it cannot be used because of lack of sufficient raw material.

"Unfair base period" claims were reduced somewhat in World War II when "limitation" orders were introduced which forbade the use of copper, for example, ${ }^{64}$ in the manufacture of certain listed articles. This approach recognized that the only permanent solution to materials scarcity was to reduce permissible demand to the size of supply. The allocation job would be substantially reduced in size and complexity, and normal channels of distribution could be relied upon to accomplish a major part of the task. This principle proved sound. Orders like that controlling aluminum ${ }^{65}$ later revised the tactic, but not the basic approach, by providing that aluminum could be used only in the manufacture of articles appearing on a list attached to the order.

One difficulty with this approach was that to a certain extent it shifted shortages from one material to another, since orders did not prohibit the manufacture of a nonessential article, but merely prohibited the use of a specified material in its manufacture. As soon as aluminum was banned, copper became scarce. From copper the demand shifted through various forms of steel, zinc, lead and finally into woods, plastics and paper, each manufacture effecting maximum substitution for the scarcer materials in his particular product.

Prohibiting the manufacture of nonessential items will have to be followed more broadly to conserve the manpower, since in the present period, manpower is expected to be a scarce item. ${ }^{66}$ This is part of the reason for the recent issuance of M-4 by the NPA prohibiting nonessential construction. ${ }^{67}$ It is important to note in this order a provision allowing application for adjustment if the applicant can show "an unreasonable

\footnotetext{
${ }_{64}$ O'Brian and Fleischmann, op. cit. supra note II, at 32; 6 Fed. Register 5394 (Ig4I).

${ }^{65} 7$ Fed. Register 539 (1942).

${ }^{66}$ Note 20 supra; DPA $\S 60 r$.

${ }_{67}$ NPA Order M-4 (Oct. 27, I950), I5 Fed. Register 7209 (I950).
} 
hardship upon him not suffered generally by others in the same trade or industry." This provision seems to lay down a proper test for handling hardship cases under the principles already discussed.

In connection with these hardship cases, it is also important to bear in mind that the defense program offers opportunities for manufacturers to convert their plants into defense work, giving them financial and other $a^{a i d}{ }^{68}$ as reviewed above.

\section{AVOIDANCE OF BIAS}

It has become particularly important in periods of emergency that all changes in the social and economic order be brought about democratically, with full opportunity for discussion and vote; changes should not be effected under the veil of emergencies. If government administrators allow their bias to be reflected in wartime economic controls, the whole program will be seriously undermined. This bias may assume the form of political favoritism for members of the party in power, favoring expansion of certain economic practices with discrimination against opposing practices, and favoring development of certain basic social-economic principles.

Examples of how the new Defense Act has attempted to prevent exercise of bias are the requirements that: (a) wage stabilization controls shall be consistent with the Labor Management Relations Act of $1947^{69}$ (b) business practices shall not be changed except where necessary to prevent circumvention or evasion of controls; $;^{70}$ (c) trade and brand names and grade labeling shall not be restricted; ${ }^{7 x}$ (d) no standardization shall be accomplished except where no practicable alternative exists; ${ }^{72}$ (e) no price ceilings shall be imposed on classes of commodities that were not "in general use in the trade" prior to such order. ${ }^{73}$

Further protection from bias is afforded by the provisions which permit an injunction to be obtained against enforcement if a regulation can be shown to be arbitrary or capricious ${ }^{74}$ and which require the AttorneyGeneral or the FTC to make surveys for Congress determining whether the defense controls are tending "to eliminate competition, create or strengthen monopolies, injure small business, or otherwise promoté undue concentration of economic power." 75

${ }^{68} \mathrm{DPA} \S 3$ \%.

${ }_{69}$ See Conference Committee Report No. 3042, 8Ist Cong. 2d Sess. 35 (Aug. 3I, I950).

${ }^{\circ 0}$ DPA $\$ 402$ (g).

73 DPA $\$ 402$ (h) (4).

75 DPA $\S 402$ (h) (r).

${ }_{74}$ DPA $\S 408$ (b).

22 DPA $\S 402$ (h) (2).

${ }^{75}$ DPA $\$ 708$ (e). 
A cardinal rule for limiting the operation of bias might be to alter normal business practices to the smallest extent possible and to challenge each change on its absolute necessity. It is suggested that this rule be used as a guide by the NPA in the exercise of its wide powers as well as by the other agencies described above. ${ }^{76}$ Business advisory committees ${ }^{77}$ should examine all controls with the same principles in mind.

Of course, it must be observed that the above illustrations on how the new Defense Act seeks to prevent bias results also in forcing upon the economy a certain rigidity. This is undoubtedly true and leads to the prevention of certain changes that would be desirable from the public point of view and might even strengthen the defense program. However, these desirable changes are not the task of the defense agencies. Public confidence in the whole defense program would be undermined if these agencies attempted any changes not of an absolute military necessity. The most that the agencies and the business advisory committees might do is to point out to Congress changes believed to be desirable for the economy both in time of peace and war.

Many standardization provisions in World War II controls-inaugurated because of the absolute necessity of conserving materials and speeding production-have been continued voluntarily without change since the war as desirable from the point of view of lower prices and smaller inventory risks.

Desirable changes such as spreading the heavy concentration of power in certain industries, altering of various methods of distribution, requiring certain forms of grade labeling for public protection, and so on, should all be approached only through direct legislation on these specific matters. While in World War II, the WPB scarcely received any criticism on this subject, the OPA caused considerable complaint. One severe example was a report of the Select Committee to Investigate Executive Agencies ${ }^{78}$ which recited examples of how the OPA had violated the will of Congress in causing changes in business practices.

One final example of this aspect of our problem: The President is authorized by Title III" to "install additional equipment, facilities, processes, or improvements to plants, factories, and other industrial facilities owned by the United States Government" and to install governmentowned equipment in such plants or facilities owned by private persons;

${ }^{76}$ Note 20 supra. $\quad 77$ DPA $\S 70$ (b) (ii).

${ }^{8}$ H.R. Rep. No. 862, 78th Cong. Ist Sess. II (Nov. 15, I942).

${ }^{79}$ DPA $\S_{303}$ (d). 
the only limitation on such power is that its exercise "will aid in the national defense." There seems to be no doubt as to the President's power to convert existing government-owned plants to the production of items which could readily be supplied through contract arrangements with private companies if, in the President's judgment "national defense" would be aided. Similarly, where plants or facilities had been requisitioned, the President presumably could install the additional equipment necessary to permit the production of any and all items in competition with private industry. However, one restriction to such move might be the statement in the Declaration of Policy that these powers be exercised "within the framework, as far as practicable, of the American system of competitive enterprise." 80

It must be said here that that phrase "so far as practicable" could offer a convenient guise for exercising the three forms of bias mentioned above. In general, the powers and limitations set forth in the Defense Act do not themselves appea'r to afford any plain opportunity for discrimination or bias. However, vigilance must be exercised on the part of an active citizenry to see that this phrase is strictly applied..$^{8 \mathrm{I}}$ Legal decisions have held

80 DPA § 2. Senate Committee on Banking and Currency [Sen. Rep. No. 2250, 8 Ist Cong. $2 d$ Sess. I3 (I950)] recognized that the authority granted the President could be used to socialize the economy but expressed the intention, however, that it should "not be used to accomplish purposes, however meritorious, which bear no relation to national defense. Your committee expects that careful attention should be given in exercising these powers to assure that their exercise will be so confined."

The language in these price-ceiling provisions is almost identical with that contained in the Emergency Price Control Act of 1942 about which the Select Committee to Investigate Executive Agencies had the following to say in I943 [H.R. No. 862, 78th Cong. Ist Sess., II-I2 (Nov. I5, I942)]:

"Section $2(\mathrm{~b})$ of the act is the prohibition against the powers of the Administrator to compel changes in business practices. Notwithstanding this provision, the Office of Price Administration has gone about at will causing changes in business practices, cost practices and distribution practices by its regulations and orders. As far back as June I933 a bill was introduced in Congress having for its purpose the setting up of standardization and grade labeling. Successive attempts were made both in the House and Senate to enact legislation of this character but each time the Congress rejected such proposals. Instead of the officials of the Office of Price Administration making an effort to interpret the statute in accordance with the intent of Congress, they set about interpreting the law to give them the power to require standardization and grade labeling of commodities. By the promulgation of Maximum Price Regulation No. 306 this policy was put into effect covering packed food products. Later by the promulgation of regulation 339 the Office of Price Administration required grade labeling of hosiery."

${ }^{8 x}$ First, it is used to modify the statement in the Declaration of Policy that the controls shall be exercised "within the framework of the American system of competitive enterprise." It then appears in the second "declaration of policy" which begins the price and wage stabilization section of the Act. It is used here to modify the statement that the authority shall be exercised with "full consideration and emphasis" on various factors including "the maintenance and furtherance of the American way of life."

A similar phrase "to the extent practicable" is used in the requisition section provided for giving the former owner of any requisitioned personal property an opportunity to reacquire it.

As noted, the phrase introduces the important Section 4 or (c) of the price and wage stabiliza- 
that this phrase means "that which may be done, practiced, or accomplished, that which is performable, feasible, possible." ${ }^{\prime 82}$

\section{FAIR SHARE-SMALI BUSINESS-NEW BUSINESS}

A provision of the Defense Act that may cause considerable legal argument and speculation is the section ${ }^{83}$ requiring the President, in allocating any scarce material, to make a "fair share" available in the normal channel of distribution for "business" if a "significant dislocation of the normal distribution in the civilian market" is effected. The President is also required to give due regard to the needs of new business.

Although it is included in a section which deals with special aid to small business, this provision appears quite properly to apply to all business enterprises of any size. The term "fair share" is nowhere defined, although the expression is used elsewhere in the Act. ${ }^{84}$ Aside from the

tion provision wherever the President is authorized to give "due consideration to comparable prices, rentals commissions, etc." in issuing controls.

The word "practicable" is also used in the provision prohibiting the President from standardizing any materials or services unless "no practicable alternative exists for securing effective price control with respect to such materials or services."

Next the phrase is used in the requirement that the President "advise and consult with, and establish and utilize committees of representatives or persons substantially affected by "the price and wage stabilization regulations."

The phrase is used in that provision which requires the President to allocate through the normal channel of distribution a "fair share" of critical materials to the "civilian market" having also a "due regard" to the needs of new business.

One observer has noted that the Defense Production Act of r950 is "a noble document ... [which] comprises about $r 6,000$ words. It is majestic not merely in verbiage, however, but in vastness of objective and the profundity of its philosophy." It is important, however, that the principles of the Act (discussed herein) be not allowed to slip away through a sometimes rather faithless escape clause, "so far as practicable."

$8_{2}$ Beck v. Bd. of Comm'rs of Shawnee Cty., I05 Kan. 325, I82 Pac. 397 (rgIg).

${ }^{8}$ DPA $\S$ 70I (c) reads: "Whenever the President invokes the powers given him in this Act to allocate, or approve agreements allocating, any material, to an extent which the President finds will result in a significant dislocation of the normal distribution in the civilian market, he shall do so in such a manner as to make available, so far as practicable, for business and various segments thereof in the normal channel of distribution of such material, a fair share of the available civilian supply based, so far as practicable, on the share received by such business under normal conditions during a representative period preceding June 24, 1950, and having due regard to the needs of new businesses."

${ }^{84}$ The question of what is a "fair share" must first be answered adequately. It is nowhere defined. The term "fair" is actually used nine times in the Defence Act. It appears six times in the requisitioning provision relating first to the limitation that other means of obtaining property on "fair and reasonable terms must first have been exhausted," and then with reference to the "fair value" of the real or personal property so requisitioned.

The term is next used, along with the word "equitable," to describe the effect any proposed ceiling must have upon "sellers and buyers of such material or service and to sellers and buyers of related or competent materials and services." This requirement is repeated in the next sec- 
reference to "new business," the basic purpose of this provision seems to be to assure some share of the allocated materials to the "normal channels of distribution." In World War II, price ceilings and other controls often made it advantageous for producers to "integrate" their whole operation from the raw material to the ultimate consumer. For example, textile mills, producing unbleached so-called "greige goods," purchased finishing firms so that their goods in the greige could be sent directly to their new finishing branches, finished, bleached or processed in various ways, and then offered at higher prices to the trade. Industrial customers who normally purchased the unfinished goods from the mills were forced either to buy the unnecessarily finished goods at higher prices or to do without such goods. The above provision is expected to assure that a fair quantity of the greige goods will be delivered to industrial customers. In spite of new integration between mills and finishers, the industrial customers will obtain their goods from their "normal channels of distribution," that is, the greige goods mills.

During debate on the Act in Congress, it was contended that this provision would prove so difficult to administer as to defeat the major purposes of the Act. ${ }^{85}$ Whether these charges will prove to be true must, of course, await actual operations under the Act. In accord with the principle of avoiding discrimination and bias, it is recognized that during major military defense efforts small business enterprises must be given special aid in order to preserve their relative position in the national economy.

World War II experiences indicated that in time of shortages and actual or threatened inflation small business enterprises frequently find themselves at a serious disadvantage. They cannot so easily hire expeditors to get scarce materials and often cannot readily convert to essential work in a defense economy. Small business cannot so easily follow the government regulations which are issued at such a time. These and other problems were recognized by World War II agencies early in the war and provided for in $1942 .{ }^{86}$ Most of the provisions now appear in the new De-

\footnotetext{
tion as follows: "Any regulation or order under this title shall be such as in the judgment of the President will be generally fair and equitable. ..."

The whole expression "generally fair and equitable" is again used in describing the "margin" to be allowed the processor of agricultural commodities. The final use of the term is in the "fair share" section discussed above.

${ }_{85}$ The Defense Production Act of 1950, 12 N.A.M. Law Digest, No. 4, at 68, 77 (Sept., 1950).

${ }^{86}{ }_{56}$ Stat. 357 (I942), 50 U.S.C.A. § Iror, IrI2 (Supp., I950); § III2, repealed 6I Stat. 449 (I947), 50 U.S.C.A. § IIOr, III2 (Supp., r950).
} 
fense Act ${ }^{87}$ which seeks to encourage small business in the following ways: it provides for special governmental efforts to provide them with full information on the Act; it requires that business advisory committees include representatives of small business and non-trade-association members; it provides for especially expeditious handling of requests and applications.

The only reference to "new business" in the Defense Act is in the complicated provision discussed above requiring the President to allocate fair shares of critical material through normal channels of distribution, "having due regard to the needs of new business." ing considered here is new, civilian business.

In the best democratic tradition, the law recognized that even in a rigid war economy the opportunity ought to be allowed for private persons to start new enterprises. However, in World War II when the military demanded more of a scarce material than could be spared from civilian needs, the remaining portion for civilian users was not divided so as to provide for new enterprises. "New business" should be provided for only when supply has caught up with military demand. It was this point of view which brought about the War Mobilization and Reconversion Act of I944. ${ }^{89}$

Bearing in mind that the new Defense Act envisions a kind of partial mobilization for the American economy for many years to come, providing for the needs of new business becomes most important. In this connection, the World War II years scarcely provide any parallel. World War II experiences do provide cases where the "new business" provisions can be easily abused. For example, individuals claiming to desire to enter the burlap bag manufacturing business sought and obtained small but valuable quantities of scarce burlap for their alleged "new business." The burlap was promptly resold at high prices; such action, of course, deprived established bag manufacturers of the burlap necessary to meet the needs of their customers. It is therefore strongly suggested that the NPA set up controls with respect to new business to see that applicants desiring to speculate on their scarce materials are deprived of allocations.

\section{E. ENFORCEMENT AND APPEAL PROCEDURES}

The principle of avoiding discrimination and bias is particularly important in the enforcement of economic controls and allowing for appeals therefrom.

${ }^{87}$ DPA \& 7 Or (a), (b). $\quad{ }^{88}$ DPA \& 701 (c).

${ }^{89}{ }_{5}^{8}$ Stat. 785 (I944), 50 U.S.C.A. $\S{ }_{16} 6_{5-1667}$ (Supp., I950). 
A cardinal principle in the development of the enforcement activities of the WPB in World War II was that no individual should be punished for noncompliance in the absence of a showing of wilful violation or gross negligence amounting to wilful disregard of the regulations. ${ }^{90}$ At least some of the regulations were extensive and complicated and were frequently misunderstood. However, the WPB believed that it could fairly require business concerns to familiarize themselves with the regulations and orders applicable to their particular operations. With the increase in the quota type of controls, the WPB recognized that where a concern exceeded its quota, out of fairness to others in the industry, a compensating adjustment should be made, even though the violation was the result of an honest mistake. This adjustment, made through what was known as a "suspension order," deprived the violating firm of a whole or a portion of the controlled material for such time as necessary to equal the amount of the material that had been used in excess of the quota.

Appeals from, and enforcement procedures under, government controls offer a wide range for the concept of "fair play." Special provisions in the new act allow the filing of a protest to a price ceiling and require that the appropriate agency grant or deny the protest within thirty days of such filing. ${ }^{\text {. }}$ There is then a right to appeal to the Emergency Court of Appeals (created in World War II) which will decide whether the control is "in accordance with law or is arbitrary or capricious."

It is believed fully recognized that an undue delay in an appeal is a practical equivalent to a denial of relief. The NPA initial allocation orders all contain appeal provisions recognizing the right to complain against a discrimination not required by the exigencies of the law. ${ }^{93}$ The "Watchdog Congressional Committee" 94 provides another means of appeal.

It is evident that the NPA and other defense agencies will draw upon the experience of the WPB which found that one method of obtaining maximum fairness in the administration of controls was the formal organization of an appeals procedure applicable to all regulations and orders..$^{95}$ A distinction must be kept in mind between appeals from an order, and appeals from special authorizations granted under the order itself. For

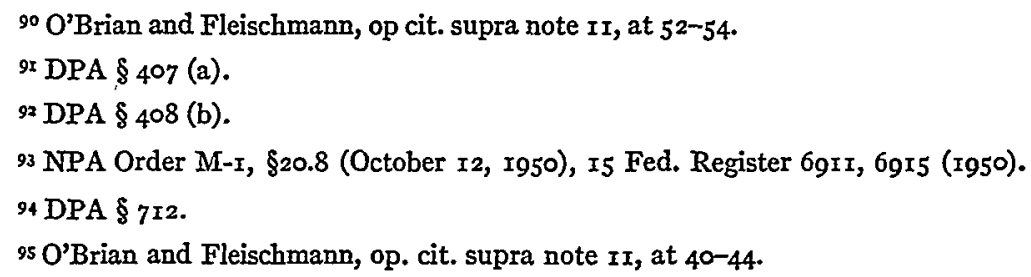


example, an order covering material $\mathrm{X}$ may have a provision that no person may have more $\mathrm{X}$ in inventory at any time than his highest inventory during 1940 and another provision that no person may accept delivery of more than one ton $\mathrm{X}$ at any time without obtaining specific permission of the WPB on a prescribed form. The first provision is for an appeal, while the second merely outlines a method of administering the order. However, if the initial application under this second provision is denied, the request for reconsideration constitutes an appeal.

World War II experience indicated that different standards and procedures were appropriate to the two cases. The second case, really a task of allocation, called for expert technical knowledge, quick decision, and occasional ruthlessness if war production goals were to be met. But in the determination of the first type of appeal-for example in deciding whether the I940 period was an abnormal period for the appellant in the first case above--technical knowledge was not so important; what was needed was a full consideration of the merits of the individual case and a decision that was as fair to the appellant as the interests of the war effort would permit.

The WPB found it impossible to formulate more specific standards for action of the appeals board than the simple statement that the board relieve cases of unusual and individual hardship. Since many orders were issued in World War II, it was not possible to predict beforehand the particular kinds of hardship which might be created or to prescribe rules for resolving cases before they arose. Standards continually emerge from experience however. For example, a three-months inventory limitation may seem perfectly fair to an industry generally, but when it appears from a large number of appeals that a year's supply of certain material must be obtained and stocked at one season of the year, it becomes obvious that the regulation needs amending.

The record of the WPB Appeals Board can not be said to lay it open to a charge of administrative despotism. In a two year period from July, I942, it heard and disposed of 42,559 appeals. Of these, 38,065 were granted either in whole or in part. .6

\section{SANCTITY OF CONTRACT}

The priority and allocation powers of the Defense Act, the requisition power, the price and wage-stabilization powers and, to a certain extent, the consumer and real estate credit controls are often necessarily exercised in such a way as to alter otherwise binding commitments in private

${ }_{96}$ O'Brian and Fleischmann, op. cit. supra note II, at 44. 
contracts between individuals or between an individual and his government.97

It is generally recognized that considerable and frequent disruptions in private contractual arrangements could play havoc with our whole private enterprise system. ${ }^{98}$ The right of an individual to contract with another and rely upon his performance is believed to be an essential part of a free enterprise system and is therefore a principle that must be preserved to every extent possible.

In respect to preserving the sanctity of contracts, it is submitted that the new Defense Act is no more drastic than the World War II provisions. Furthermore, other developments described below indicate a stronger determination to adhere to this principle than was demonstrated in World War II.

\section{A. IAW OF UNRECOVERABLE LOSSES IN MUITARY OPERATIONS}

The commandeering of private property and the juggling of contracts by government during wartime has a long history. The injured parties frequently attempt later to lick their wounds in court, but often to no avail. 99

Uncompensable losses from wartime operations have largely fallen within the common-law principle that private property may be destroyed , by government authority without compensation when such action is necessary to insure the public safety. ${ }^{\text {Too }}$ The Fifth Amendment, which prohibits the taking of private property without just compensation, is not a limitation on this sovereign power. Losses from contract defaults caused by wartime regulations are a prominent example of this class of cases.

World War II brought an unparalleled disturbance of ordinary contract relations. The unique economic and military situation today may result in a more gradual development of a strong military defense program without considerable disruption of private contracts.

The common-law principles were that, in the absence of a stipulation in a contract relieving a party in case of war, the existence of a state of war was itself no excuse for a breach of contract and the defaulting party

97 Frey, Contractual Problems of War and Peace, $3 \circ$ Va. L. Rev. I (I943).

${ }^{8}$ Frey, Unrecoverable Losses in Wartime Operations, 24 B.U.I. Rev. 57 (I944).

99 Frey, Contract Defaults and Cancellations in Wartime, 38 IIl. L. Rev. I67 (I943).

${ }^{800}$ For a review of court decisions on contract defaults arising out of World War II, see Smith, War's Aftermath in Law, 7 I A.B.A. Rep. 282 (r946); Millett, World War II: The PostMortem Begins, 6I Pol. Sci. Q. Rev. 32I (I946); Kronstein, Effect of War on Long Term Contracts, 35 Geo.L.J. 429 (I946); Schroeder, Impact of the War on Private Contracts, 42 Mich. L. Rev. 603(r944); McNair, Legal Effects of War (2d ed., r944). 
had to pay full damages. ${ }^{\text {ror }}$ While peace was considered normality, its continuance was not an implied condition of all contracts. But there were two situations which did excuse defaults and place more of the loss upon the party not in default.

The first of these was a governmental act or order that made the promised performance impossible or illegal. An example would be a WPB " $L$ " order which prohibited the delivery of items to certain persons regardless of a prior contract; another would be a price regulation which nullified a sales contract because the price was higher than that permitted by the regulation. But impossibility in law is by no means coextensive with impossibility in fact.

The second situation covers cases in which defaults were also excused where the governmental act or order substantially deprived one party to a contract of the benefit for which he had bargained. An example would be the effect of the tire rationing order on a tenant under a lease which restricted the premises to the sale of tires. However, extreme hardship, such as a sharp increase in the cost of performance by reason of war or increased difficulty in performance, is no excuse for default.

Classically, the two situations above are known as "impossibility of performance" and "frustration of purpose." situations is the default excused where there is a "contributing fault" on the part of the defaulting party.

The reported cases arising from the wartime regulations reaffirm the above-mentioned common-law principles. ${ }^{\mathrm{x} 3}$ Most of these cases deal with the return of deposits and of items traded in for products the delivery of which became prohibited. In another type of case, the buyer contracted to buy rayon when his inventory of rayon was already at the maximum permitted by the WPB. The Court held that since the contract was not illegal when made, the seller could recover damages for the buyer's refusal to accept delivery, for the buyer could have sold enough of his inventory to take delivery or he could have assigned the contract to a third party; or could have appealed to the appropriate government agency for relief. ${ }^{\text {.04 }}$

${ }^{\text {rox }}$ Authorities cited note roo supra.

ros Ibid.

203 Ibid.

${ }^{204}$ Federated Textiles, Inc. v. Glamour Girl, Inc., 265 App. Div. 252, 38 N.Y.S. 2d 493 (1942) (buyer's failure to act constituted a contributing fault). For common-law principle of private property being destroyed for purpose of public safety, see Campbell v. United States, 266 U.S. 368 (I924); Sharp v. United States, I9 I U.S. 34I (I903); Hawaii v. Honolulu Plantation Co., Ltd., 34 Hawaii 859 (I939). For cases on the suspension or dissolution of performance of a contract, see Atlantic Steel Co. v. R. O. Campbell Coal Co., 262 Fed. 555 (D.C. Ga., r919); Black \& Yates v. Negros-Philippine Lumber Co., 32 Wyo. 248, 23I Pac. 398 (I924); see 


\section{B. "EXCULPATORY CLAUSE" OF PRESENT DEFENSE ACT}

While the social justification of a legally binding contract is to prevent wasteful controversy between the parties, its commercial advantage is that by its terms the parties believe they have settled upon each other the various burdens of financial risks involved in the agreement and that they therefore pursue their other business functions accordingly.

However, the public urgency of a military defense program sometimes requires the government to disrupt such contracts; the means by which this may be done is specified by Section 707 of the Defense Production Act of $195^{\circ}$ :

No person shall be held liable for damages or penalties for any act or failure to act resulting directly or indirectly from his compliance with a rule, regulation, or order issued pursuant to this Act, notwithstanding that any such rule, regulation, or order shall thereafter be declared by judicial or other competent authority to be invalid.

Except for one difference, this provision is the same as appeared in the World War II statute and was known as the "exculpatory clause."Ios The term "act" is used above, whereas earlier provisions contained the term "contract default." This change would seem to indicate that tort claims as well as contract claims are to be embraced by the revised "exculpatory clause."

Congress' intention in enacting this provision may be understood in the light of the common-law rules relating to war already discussed. A manufacturer's failure to fill an order carrying no preference rating where his entire output had been sold on rated orders has been held excused as a true instance of common-law impossibility, without regard to the possibility that his plant might have been expanded. Congress believed in World War II, however, that the case of a producer who altered his plant's facilities to obtain war orders, perhaps as an escape from filling less profitable nonwar contracts, might constitute a "contributing de-

generally 6 Williston, Contracts $\$ \S$ I957-8 (rev. ed., I938). On the frustration doctrine, see Federal Sign System v. Palmer, I76 N.Y. Supp. 565 (I9I9); Rest., Contracts $\S 288$ (I932); general discussion in Pedrick \& Springfield, War Measures and Contract Liability, 20 Tex. L. Rev. 7 ro (I942); Deibler v. Bernard Bros., Inc., 3 Ig Ill. App. 504, 48 N.E. $2 d$ 422 (I943) (lease providing for auto showroom and garage and for no other purpose held valid). The restraint on the war power under the Fifth Amendment is like the restraint on the state police power imposed by the Fourteenth Amendment. Hamilton v. Kentucky Distilleries \& Warehouse Co., 25 I.S. 146 ( $\left.\mathrm{rg}_{9} \mathrm{~g}\right)$. While there is restraint in theory, actual holdings of invalidity are almost nonexistent. O'Rourke, War Powers, 8 Geo. Wash. L. Rev. 157 (r939). See also Brown, Effect of Conscription of Industry on Contracts for the Sale of Goods, 9० U. of Pa. L. Rev. 533 (1942); War-Effect on Iandlord-Tenant Relationship, I2 Brooklyn L. Rev. I20 (1943).

${ }^{505} 54$ Stat. 676 (1940); 56 Stat. $\times 80$ (1942). See Blair, Breach of Contract Due to War, 20 Col. L. Rev. 4I3 (I920); Dadd, Impossibility of Performance of Contracts Due to WarTime Regulations, 32 Harv. L. Rev. 789 (r9I9). 
fault." ${ }^{x_{06}}$ Therefore, to encourage producers to switch to war production, Congress enacted the "exculpatory provision," with the purpose of restating the rule of impossibility to include the doubtful case mentioned above. The "exculpatory provision" also embraces the doctrine of "frustration of object."

The constitutionality of the "exculpatory provision" may be challenged on the grounds that it deprives those adversely affected of property without due process of law, and that it is an encroachment by the federal government upon the police powers reserved to the states by the Tenth Amendment. The first of these challenged may be met by the argument that although the Fifth Amendment places a certain limit on the war powers, the valid exercise of the war powers extends to all matters related to winning of the war and to the employment of all appropriate means to wage war successfully. ${ }^{107}$ Congress is left with the responsibility of determining what are the necessary means for successfully waging the war. As for the second objection, it is important to keep in mind that while the Constitution forbade the states from passing laws impairing the obligations of contract, no specific limitation is imposed upon the federal government. Such a provision never has been within the police power. Congress may pass such a law if it is incidental to its constitutional power to wage war. ${ }^{\mathrm{x} 8}$ The exculpatory provision appears, therefore, to be a valid exercise of the war power.

A new provision in the Defense Act, following directly after the above quoted "exculpatory clause," prohibits discrimination against priority or allocated orders by charging higher prices or imposing different terms. ${ }^{\text {xo }}$ This should help prevent the abuse in World War II where contractors, anxious to be relieved of certain private contracts for various items, sought to obtain priority orders from the government for these same items on more favorable terms and at higher prices.

For the obvious reason that the question of proper damages recoverable under a defaulted contract is a matter for the courts, the law of the particular state involved, and the special effect on that contract of the "exculpatory provision," the several agencies have refused requests to interpret the effect of the provision on each particular situation. Many settlements may, however, be reached by the application of certain basic tests to the various special situations. In what follows are submitted the

\footnotetext{
${ }^{206}$ Note 104 supra.

${ }^{207}$ Authorities cited note roo supra.

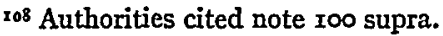

${ }^{209}$ DPA \& 70\%. 
basic tests grouped together under what are believed to be the five major classes of problems arising from contract defaults during defense efforts:

\section{r. Defaults after Inability To Secure Materials}

The priority technique applied to the distribution of supplies has made it impossible for a large number of sellers and contractors, whose undertakings do not justify priority assistance, to secure materials or goods. Under the wording of the "exculpatory clause," the seller or contractor who is unable to secure supplies because of the priorities or allocation program must show that default in performance is ascribed to compliance with some regulation or order. That performance was not illegal does not defeat the defense of impossibility in other situations, such as where specific goods are destroyed. When, as sometimes happens, the priority regulation by its terms forbids purchase of the needed material, save on a license not obtainable by the defendant, a resulting breach of contract is clearly excused by the statute.

Generally, no problem of causation is presented in any case where all of a material or class of goods is entirely allocated to war or essential civilian production, or exhausted by preference rating. The injured party should ascertain whether the defaulted party may not complete the contract while still complying with the regulation. All steps permitting completion of the contract prescribed by the applicable regulation should be exhausted. Failure to exhaust all remedies would constitute a "contributing fault." The defaulting party must not, of course, be required to go to a "black market," for example, to obtain material to complete his contract. However, if there is in fact some material available for nonessential use; and the defendant loses out because of lack of diligence or because he is not an old customer of the supplier, a more troublesome question is presented. Denial of relief would seem proper.

\section{Defaults after Frustration of Object of Contract}

Extreme hardship, such as a sharp increase in the cost of performance by reason of war, or increased difficulty of performance, is not excused. Unless a lease expressly limits the usage of the premises or machine to the prohibited or substantially restricted purpose, the lessee remains liable. Where a lease does not restrict the use of the premises, the "default" may be said to result at least as much from the failure of the dealer to utilize his premises for a new purpose. The general rule must be that where the curtailment operates to leave so insubstantial a quantity of merchandise for resale that the beneficial use of the premises have been virtually destroyed, the tenant is not liable for future rent. The "exculpatory pro- 
vision" may be said to stretch the common-law rule so as to cover the former peripheral cases. It does not seem that a party should be excused from default on a long-term lease where, for only the time being, the use is restricted and unprofitable. In the past it may have been profitable, and later on may again be profitable, so that the tenant should on principle not be relieved merely because the premises have temporarily become useless to him.

\section{Defaults after Consideration of Partial or Substituted Performances}

Defense measures interfering with performance of private contracts may prevent complete literal performance but permit a partial or substitute performance. Thus a manufacturer may, at the time the prohibition order against further production becomes effective, have on hand enough goods to fill half of his outstanding contracts. Likewise, on a construction project the specified material may be unobtainable but a reasonably adequate substitute may be available. With respect to a sales contract, it is the duty of the seller to deliver as much as possible and prorate the supply when there are several outstanding contracts. With respect to substitution of material, the same considerations should apply. If the substitution will not impose a greater burden on the contractor, the contractee should be entitled to insist upon it.

\section{Defaults after Consideration of Suspending Instead of Cancelling Con- tract}

The nature of the interference with a contract may in some instances suggest that both parties should agree to suspend its operation temporarily. In cases of governmental interference with charter parties, contracts for the sale of unspecified goods and construction contracts, in all of which performance is intended to take place over a period of time, the possibility of suspension as an alternative to dissolution is presented. The formula by which the issue is resolved is that if the interference will be of such duration that performance thereafter would be substantially different from that contemplated by the parties at the time of entering into agreement, then the impossibility effects a dissolution of the contract, and an inordinate delay may be taken presumptively so to alter the character of the undertaking. ${ }^{\text {Iro }}$ When the restrictive measure contains a specified expiration date, as is true of some priority regulations, a special problem is presented. Considerations relevant to solution of the suspension-

${ }^{\text {rro }}$ For collection of cases on questions of suspension or dissolution of contracts, see Rest, Contracts $\$ 462$ (I932). See duty to give partial performance, 6 Williston, Contracts $\S 1956$ (rev. ed., I938). 
dissolution issue in such a case are the length of time specified for the prevention, the likelihood that the regulation will be extended, the nature of the contract and the probable effectiveness of price control and other governmental measures in stabilizing the cost of performance over the period involved.

\section{Defaults under Contracts Dranem by Parties Who Contemplated Controls}

With respect to a contract entered into when both parties had a real appreciation of the possible interposition of performance-defeating control measures, there are several American decisions, ${ }^{1 \mathrm{II}}$ some ordinary impossibility cases and some growing out of war-time conditions, where the view has been taken that if the performance-defeating contingency is foreseeable, failure on the part of the seller or contractor to put an exculpatory clause in the contract is fatal, for the defense of impossibility is not available under such circumstances. The legal issue, therefore, in this kind of situation is whether the contingency of cessation of supply through preemption by preferred buyers was a commercial risk undertaken in the contract. The "exculpatory provision" is not limited, however, to contracts entered into before the war, and by its terms it is applicable in any case where a default results from compliance with a regulation or order. Moreover, the purpose of the statute, manifestly to stimulate war production by easing the pressure caused by an urgency toward the completion of nonessential contracts, requires that it be applied without regard to the possibility that the contracting parties might have been able to foresee the course of the war-production program. The provision applies to both interstate and intrastate transactions.

Probably a provision in any contract in which the party promised to pay damages if he is forced to default due to some regulation or order may be declared illegal and contrary to public policy. All provisions in contracts dealing with cancellation charges seems to be unenforceable by reason of this statute, whether the contract was signed before or after the enactment. On the other hand, the "exculpatory provision" does not prevent the parties from settling a contract default according to whatever terms are mutually agreeable to both of them. Parties to such defaulted contracts have such questions to settle as the storage charges for the prohibited material, or interest at the bank for financing the purchase or production of the new restricted material. Certainly a manufac-

${ }^{11 x}$ Cases where performance-defeating contingency is foreseeable: Day v. United States, 245 U.S. I59 (I9I7); Berg v. Erickson, 234 Fed. 8I7 (C.A. 8th, I916). 
turer may recover the reasonable value of the parts shipped and accepted by his customer or else have these parts returned.

Where the rules stated above provide no assistance in the settlement of a particular financial loss, consideration should be given to provisions in the governmental regulations suggesting methods to minimize the losses. Governmental regulations are drawn with the purpose of lessening contract defaults as much as possible. In many cases, the various orders will exempt from the restrictions material already partly assembled, on hand, or in transit. Many orders tighten the restrictions gradually, thus allowing time for many contracts to be completed.

Only in special cases will the federal district courts have jurisdiction over suits involving the "exculpatory provision." The Supreme Court may review such a case by certiorari after final judgment by the state court.

\section{THE GOVERNMENT'S CONTRACTUAL RELATIONS}

It is important to note the role that the government procurement agencies can play in the preservation of the sanctity of contracts in this matter. For example, the "defense financing powers" of the new Act envision the happy fact that mechanisms ${ }^{\mathrm{rr} 3}$ were developed in World War II to provide for speed, fairness and finality in the settlement of government contracts that are terminated. Uniform rules were established, "settlement officers" especially trained, a single review board set up. This development was seen necessary then for the continued successful prosecution of the war and also to avoid bankruptcy of industry in the transitional and post-war periods. The last few years have seen the establishment of uniform procurement regulations that form a basis for common procedure and practice covering such matters as contract form and clauses, patents, invention and copyright, bonds and insurance, taxes, labor and contract cost principles.

In case of a contract cancellation, the common law provides that the contractor may recover the entire contract less the amount of cost saved to him by not being required to complete the contract. ${ }^{\mathrm{Ix}}$ Because this principle is more liberal in respect to profit than the government is willing to permit and because a determination of the profits by court procedure or by arbitration always involves delay and uncertainty, the parties have

II2 DPA § 3 or.

${ }^{213}$ See Office of Contract Settlement, A History of War Contract Termination and Settlements (I947); Baruch \& Hancock, Report on War and Postwar Adjustment Policies (I947).

134 Authorities cited note Ir3 supra. 
usually preferred writing into the contract an arrangement which gave more certainty. The situation once existed that the prime contractors had agreements with the subcontractors which did not contain effective cancellation clauses. Legally, therefore, it was possible for a subcontractor to recover against the prime contractor for termination of the subcontract in an amount exceeding that which the contracting officer for the government would approve for reimbursement to the prime contractor.

\section{ANTICIPATION OF SUDDEN DEFENSE EFFORTS}

If major defense efforts and attending controls must increase in frequency for the United States (until world law is developed or the burden of keeping the peace is spread more equally), our own private enterprise system is threatened unless some means is achieved of writing long-term contracts of sufficient certainty and simplicity under such conditions. Tragic as it is, the old common-law concept of "peace as a normalty" in the making of contracts must now be modified so as to narrow, if possible, that greatly widening class of "unrecoverable losses in wartime operations," also known as the "fortunes of war."

To prevent wasteful controversy over future contract defaults through economic controls, it is suggested that provisions be included where possible in contracts which will: (I) provide what the parties shall do in the event of some future interference, as for example, specifying expressly the duties to complete performance under a contract where a control makes the promised course of performance impossible (for example, partial or substituted performance); (2) provide for temporarily suspending performance in certain events but permitting written notice of cancellation by either party at any time; (3) specify in rental and service contracts the precise "object", of the contract and the degree of frustration which will permit cancellation; (4) provide in purchase contracts a clause permitting cancellation if "at the date of receipt" of goods acceptance will place the buyer in violation of a government regulation or action relating to inventory restrictions.

The question of making forward contracts is naturally presented. Can long-term deals now be made with any assurance that there will be no loss if price curbs intervene? What is the status of contracts for delivery after a price ceiling order? In answer to these questions, look at the following situations.

Case $I: \mathrm{X}$ contracts to deliver merchandise to $\mathrm{Y}$ at $25 \%$. Before delivery, Washington sets a rolled-back price ceiling of $23 \hat{k}$.

Since the interpretation of contract law differs by states, a specific 
answer is difficult here. In general, it would seem that the courts will

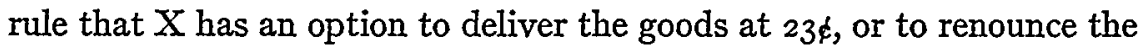
agreement altogether.

As a practical matter, if the terms other than price are agreeable to $X$, he can carry out the transaction. If the collateral terms aren't 'agreeable, $\mathrm{X}$ is in a position to claim that the price was the heart of the contract, so it's void. Y wouldn't have this option; in effect he loses the chance to sew up a source of supply for an indefinite period of time.

Case 2: $\mathrm{P}$ contracts to deliver merchandise to $\mathrm{Q}$ for $25 \%$. The price rises to 30 and then Washington sets a ceiling at $29 \%$.

In this case, courts ought to be reluctant to release $P$. In case $I, X$ would lose if he sold to $\mathrm{Y}$ or to another buyer, but in case $2, \mathrm{P}$ would gain by selling at 29 to someone else. Courts are not likely to let him take a free ride on the ceiling.

Case 3: $\mathrm{C}$ and D agree to open price, as of delivery. Washington rolls the price back so that $\mathrm{C}$ would deliver at a loss. In this situation there is no hope for C, except by a government order. As discussed above, the Defense Production Act permits the President to prevent hardship to sellers caught with such contracts for future deliveries, but only where such deliveries are normal or demanded seasonally.

Case 4: Before the Korean development, A contracted to sell goods to B for delivery at a date which is now approaching. Many sellers are caught with such low-priced, pre-Korea contracts. A general price roll-back to pre-June 24 levels is the only hope for such sellers.

Some sellers report that they have been able to arrange amicable adjustments of the contract price on the basis of mutual good will and voluntary arbitration.

In making contracts today, buyers will want fixed prices, sellers will prefer escalator price clauses. In any case, both parties should consider the contingency that a price order may be issued by Washington before the delivery date. A clause may provide that all but price terms will remain in force; or both parties may be given an option to set the contract aside.

The several suggestions above, regarding contract making with government controls pending, reflect the type of arrangements made early in World War II.

\section{EnCOURAgement of Voluntary Controls}

The strength of democracy is in the degree of voluntary control its people are willing to exercise both individually and cooperatively in meet- 
ing their common goals. While the Defense Act gives the President power to provide for mandatory regulations, it contemplates accomplishment of its objectives in the first instance through voluntary agreements and programs by various segments of the economy. ${ }^{115}$ Consequently, procedures have been established to provide anti-trust protection for co-operative action undertaken at the request of the President. ${ }^{\mathrm{rr}}$

The new Defense Act goes beyond any previous statute in urging voluntary actions. "Voluntary action" by "business, agriculture, labor and consumers" to meet one or more of the objectives of the Act are to be encouraged by the President. ${ }^{\text {Ir }}$ Any "voluntary programs" developed to this end may be approved by the President for anti-trust exemption, and a specific procedure is set up to protect the voluntary participants.

These provisions are concerned solely with co-operative "action" of a voluntary nature by classes of individuals and not with the field of voluntary action by single individuals or firms-so important in any program, governmental or otherwise. Actions of individual concerns produce no fears of anti-trust suits and require no blanket or statutory provisions.

Only after Pearl Harbor, when thousands of manufacturers individually and promptly converted to war work, and thousands of workers sought out defense jobs, was the vast, military production program assured of

Irs DPA § зоr.

II6 DPA \& 708:

"(A) The President is authorized to consult with representatives of industry, business, financing, agriculture, labor, and other interests, with a view to encouraging the making by such persons with the approval by the President of voluntary agreements and programs to further the objectives of this Act.

"(B) No act or omission to act pursuant to this Act which occurs while this Act is in effect, if requested by the President pursuant to a voluntary agreement or program approved under subsection (a) and found by the President to be in the public interest as contributing to the national defense shall be construed to be within the prohibitions of the antitrust laws or the Federal Trade Commission Act of the United States. A copy of each such request intended to be within the coverage of this section, and any modification or withdrawal thereof, shall be furnished to the Attorney General and the Chairman of the Federal Trade Commission when made, and it shall be published in the Federal Register unless publication thereof would, in the opinion of the President, endanger the national security.

"(C) The authority granted in subsection (b) shall be delegated only (I) to officials who shall for the purpose of such delegation be required to be appointed by the President by and with the advice and consent of the Senate, unless otherwise required to be so appointed, and (2) upon the condition that such officials consult with the Attorney General and with the Chairman of the Federal Trade Commission not less than ten days before making any request or finding thereunder, and (3) upon the condition that such officials obtain the approval of the Attorney General to any request thereunder before making the request. For the purpose of carrying out the objectives of Title I of this Act, the authority granted in subsection (b) of this section shall not be delegated except to a single official of the Government."

Ir7 DPA § 708. 
success. ${ }^{\text {II8 }}$ In the present defense effort, there exist still further opportunities for individual voluntary action in seeking out defense orders, in voluntarily reducing inventories of scarce materials, in refusing to speculate on scarce items, in offering to expand production facilities, in reducing nonessential construction, and so on.

"Voluntary programs" in which groups of individual firms agree to bind themselves to follow certain ends are very similar to NRA programs. ${ }^{\text {Irg }}$ These co-operative, voluntary programs have several advantages, as compared with compulsory, governmental controls seeking to accomplish the same ends; they do not stimulate bureaucratic growth in government and departments; they produce a measure of greater freedom and win more public support. On the other hand, the danger of cartelization in these voluntary programs is always great.

At this point, it is proposed to discuss three aspects of this principle of encouraging voluntary actions. These are: (I) voluntary programs that affect the economy; (2) voluntary assistance by business men in helping to guide controls; (3) voluntary participation in factual studies and aiding in understanding of the controls.

\section{A. VOLUNTARY PROGRAMS}

Previous experiences with voluntary actions have to some extent been disappointing. In World War II, the system of voluntary priorities was rapidly abandoned. Early in February, I94I, OPM (predecessor of WPB) began ordering the machine-tool industry to observe priorities. As of this writing, high-tenacity rayon producers are attempting to work out with the NPA a voluntary allocation plan. A voluntary steel allocation plan is already under way. Each steel customer feels that his own supply problems are unique and deserve preference. The list of steel users seeking priorities is growing daily. Further pressure is in sight, for many industries are organizing committees to promote larger steel deliveries. With the list growing so rapidly, however, the voluntary allocations program of the steel industry is endangered, and it may become unworkable. Freight-car builders, coal operators, steel container manufacturers, furnace builders, pipeline operators and cabinet makers are only a few of the users seeking more steel.

The chief difficulty in any such program is the question whether actions thereunder will not be regarded later as anti-trust violations. The anti-

II8 O'Brian and Fleischmann, op. cit. supra note II, at 5 .

${ }^{\text {Ix9 }} 48$ Stat. r95 (1933), declared unconstitutional in Schechter Poultry Corp. v. United States, 295 U.S. 495 (I935). 
trust exemption provision of the Act is built upon the experience of World War II where the WPB General Counsel approved a considerable number of voluntary programs. ${ }^{120}$ What is new is that the FTC will also be advised.

It must be emphasized that the necessity for the exercise of caution exists, lest the overzealous efforts of government officials and businessmen, co-operating in such programs, carry the operation beyond the prescribed limits and into areas not protected by the immunity. Experiences under NRA and World War II controls offer many examples which warrant such caution.

\section{B. INDUSTRY ASSISTANCE TO GOVERNMENT}

Where encouragement of voluntary action by government or "jawbone controls" fail to meet defense objectives, the next step, of course, is to impose compulsory controls. Such controls, however, can be substantially tempered by the assistance of industry, labor and consumer groups by advising government agencies regarding such controls. In this connection, business advisory committees have been developed through two world wars and during various peacetime projects of national importance. ${ }^{x_{2 x}}$ These committees constitute one form of voluntary effort and bring experienced business advice to the government agencies.

In respect to price and wage controls, the Defense Act requires the President to consult with "representatives of persons substantially affected by" controls. ${ }^{12}$ This would seem to include labor groups as well as industry. As respects all the controls, the Act requires a "fair representation for independent-small, for medium, and for large business enterprises, for different geographical areas, for trade association members and nonmembers, and for different segments of the industry" on these "business advisory committees." ${ }^{123}$ This provision embraces substantially the policy of the WPB during World War II.

${ }^{220}$ Under the World War II statute, voluntary programs were announced in the Federal Register as required under the present act. For example, these were some of the subjects in World War II: No. 2 (use of asphalt or tar products on roads); No. 4 (production and distribution of newsreels); No. 5 (jewel-bearing manufacture); No. I2 (proposed co-operative venture of eight firms in production of aviation gasoline). See Gerge, Anti-trust Enforcement in War and Post War Period, I2 Geo. Wash. L.Rev. 371, 377-82 (1943).

x2x DPA § yor (b) (ii):

"Such business advisory committees shall be appointed as shall be appropriate for purposes of consultation in the formulation of rules, regulations, or orders, or amendments thereto issued under authority of this Act, and in their formation there shall be fair representation for independent small, for medium, and for large business enterprises, for different geographical areas, for trade association members and nonmembers, and for different segments of the industry."

122 DPA \$404.

I23 DPA § 70I (b) (ii). 
The Act also attempts to assure industry consultation ${ }^{124}$ by requiring that all regulations issued "must be accompanied by a statement that industry representatives, including trade association representatives, have been consulted." The specific Congressional instruction to consult trade association officers is new, and evidently reflects greater recognition of the assistance trade associations can give in providing statistical data about the particular industry. It constitutes a challenge to co-operative groups within industry to provide substantial assistance to projects in the public interest.

Where voluntary co-operative action has been frustrated by what the President calls "a few chiselers" in an industry and compulsory controls are required, then representative advisory committees can help to guide the controls along the best possible course. ${ }^{125}$ These committees must constitute a true cross-section of the industry.

In World War II, the industry advisory committees proved to be an instrument of great value in making price controls both effective and reasonably equitable. The committee members provided valuable expert help. It is of importance, therefore, to attempt to gauge to what extent similar committees will be permitted to operate under the new Act. Under the ${ }^{1942}$ Act, ${ }^{126}$ the committees had a very definite status and were self-governing under the general OPA regulation No. I3. Their establishment could be requested by the industry, and upon proper showing of representation the Administrator was required to appoint the committee. Once appointed it had statutory power to organize and conduct its own meetings.

The OPA statute gave an industry committee power to make recommendations to which the Administrator was required to give consideration. The provisions in the present Act are quite different. Reference to such committees and references to consultation with industry representatives appears not in a single well-integrated section but in several scattered subsections. ${ }^{\text {I27 }}$

What powers will industry committees have? To what extent will their efforts receive recognition at the administrative level? This is answered

${ }^{224}$ DPA $\S 402$ (c).

r25 President Truman, Radio Address of Sept. 9, I950. The President said: "But controls will still be necessary in some cases where voluntary individual action is not enough or where the honest majority must be protected from a few chiselers." The steel industry's representatives are still strongly claiming at this writing that they can accomplish the Act's objectives through voluntary action.

$$
{ }^{226}{ }_{5}^{6} \text { Stat. } 23 \text { (r942). } \quad \text { r27 DPA } \$ \S 402,404,701 \text { (b) (ii), } 709 .
$$


in part by a section dealing with administrative procedure applicable to the entire Act. ${ }^{128}$ It would appear that the President or his delegated authority may by-pass committee consultation by a finding of "impracticability" or a situation contrary to interest of the "national defense." In this connection NPA Regulations I and 2 (already issued) both state that:

Consultation with industry representatives in advance of the issuance of this regulation has been renidered impracticable by the fact that the regulation affects all trades and industries. ${ }^{229}$

Therefore, it seems that the role of industry committees in the development policies under this new Act is not clearly defined. Committees, as such, are provided for but not as in the industry committee section of the Price Control Act of I942. Industry is given no right to request such committees, nor are they self-governing under the terms of the statute. There is the limited statutory requirement and their recommendations be given consideration by the Administrator but he need not consult the committee if he deems it "impracticable" or not in the interest of the national defense.

On the other hand, as pointed out above, the statute provides that in connection with wage and price controls the committees shall be representative of "persons substantially affected by regulations or orders issued thereunder." This language would permit the appointment of labor and consumer representatives as well as representatives of the business interests involved. This is consistent with numerous public statements which have appeared that labor would insist upon representation "on the ground floor" of any wage or price control agencies. What is more encouraging in the Defense Act is that in addition to the rather vague provisions for industry advisory committees, there are other provisions envisioning the assistance of individuals of "outstanding experience and ability without compensation" and the employment of "experts and consultants for organizations thereof." ${ }^{130}$

Apparently these provisions are intended to give the President complete freedom to recruit competent persons to assume responsible positions in the administration of the Defense Production Act. Presumably such appointees "without compensation" would not need to sever their private business connections in order to perform public service. Thus this section should make it much easier to secure capable and experienced men to serve in the administration of the Act.

${ }_{128}$ DPA § 70I (b).

${ }^{129}$ Authorities cited note ro supra.

${ }^{130}$ DPA $\S 710$ (a), (b), (c). 


\section{FULL INFORMATION ON CONTROIS}

It seems clear that voluntary support of governmental objectives can be more easily secured by frank revelation of all the facts making the various controls necessary. This is really only one result of the general tenet that the advancement of democratic government depends upon an enlightened and fully informed public.

The new Defense Act recognizes this vital aspect in various ways. As in World War II, the law requires that regulations and orders be accompanied with a statement of the considerations involved in their issuance. ${ }^{\mathrm{r} I \mathrm{I}} \mathrm{A}$ joint congressional committee is set up to "make a continuous study of the programs authorized by this Act." ${ }^{232}$ The President is authorized to require reports and to insist upon record keeping by business firms. ${ }^{x 3}$ Where price ceiling protests are denied, the President must reveal the ground on which such decisions are based and "any economic data and other facts" of which official notice was taken. ${ }^{\mathrm{x}}{ }^{34}$

A special problem in World War II was the "blizzard" of forms, questionnaires and reports. In December I942, the Congress ordered the Budget Bureau to "clear" all papers going to industry with a view toward simplifying and reducing the amount of necessary factual data needed..$^{\mathrm{r} 5}$ There is evidence that this same control will exist under the national defense program.

It is important to remember that wartime controls do not follow the same pattern in each war, and vigilant scrutiny must be maintained. In World War I, wheat was the first important commodity subjected to price regulation and one of the first to be put under use controls. In World War II, prices of wheat were one of the last put under controls, and there were no use restrictions upon wheat until March I946. (The difference statistically was that there was a large excess supply of wheat during most of World War II.)

Factors to be considered with the new controls are that the increased defense expenditures during $195^{\circ}$ are not expected to exceed three per cent of national production, and possibly fifteen per cent the next couple years -this in contrast to World War II's military program which absorbed

$$
\begin{aligned}
& { }_{331} \text { DPA } \$ 402 \text { (c). } \\
& { }_{332} \text { DPA } ₹ 712 \text { (b). } \\
& { }_{333} \text { DPA } ₹ 705 .
\end{aligned}
$$$$
{ }^{334} \text { DPA } \& 407(a) \text {. }
$$

${ }_{335}$ Budget Bureau Clearance data; see Wilkie, Legal Basis for Increased Activities of Federal Budget Bureau, II Geo. Wash. L. Rev. 265 (I943). 
one-third of the country's production. ${ }^{136}$ Today America's total manufacturing capacity is fifty per cent greater than it was ten years ago.

Certainly vital to all democratic processes are procedures designed to bring all individuals to a full understanding of the purposes and contents of each control and confidence in its efficacy. Too often, resentment at governmental regulation is the result of a lack of understanding of the necessity of the action being taken. The importance of a full explanation was appreciated in the case of the first copper allocations order in World War II. The press release issued at the time referred to the order as "the most far-reaching action of its kind yet taken" and gave in some detail the reason for the order. The current monthly demand and supply situation was given as well as estimates for a year ahead, with an explanation of the other steps which were being taken to expand the supply and to curtail the less essential use of copper. ${ }^{137}$

A special safeguard to arbitrary actions of the governmental agencies is the above mentioned provision setting up a "watchdog" congressional committee, the Joint Committee on Defense Production..$^{{ }^{38}}$ It provides another source of appeal by various groups who will seek changes in the controls issued.

Presumably, therefore, the committee will be vigilant to prevent some of the administrative abuses of discretion, which arose during the last war, ${ }^{139}$ and also provide a forum for those who might feel they are being discriminated against in the application of rules, regulations and orders issued under authority of the Act.

Analysis of this final aspect of the principle of encouraging voluntary participation in the meeting of common goals has been appropriately summarized by General Eisenhower:

But in the cutting edge that is the armed forces, we have only a partial strength. The nation's economy, the skill of its workmen, its mass production and the ability of the average citizen to comprehend world issues are just as important. The basic struggle of our time - of the human against the state-is going to be won for our side only if we live by the truth and base our campaign on truth. ${ }^{140}$

${ }^{x 3^{6}}$ At time of passage of the Act, the estimate was only $3-15 \%$ of the total production per year for military. See Chicago Journal of Commerce, p. I (Nov. I3, I950), with regard to an NPA evaluation of all industries consuming critical materials. Compare American Economic Mobilization: A Study in the Mechanism of War, 55 Harv. L. Rev. 427 (I942).

${ }_{337} \mathrm{O}^{\prime}$ Brian and Fleischmann, op. cit. supra note II, at 3 I.

${ }^{238} \mathrm{DPA} \S 7 \mathbf{2} 2$.

${ }^{3} 39$ See Baruch, American Industry in the War (I94r).

${ }^{140}$ See article in N.Y. Times, p. 44 (Sept. 27, r950). While our nation's peaceful and unselfish intentions with the other nations of the world need considerable clarification by word 


\section{SUMMARY}

While it is difficult to remain calm in an atomic era where world law and justice are unfortunately still in adolescent stages, there remains a duty to work diligently to maintain democratic principles during the military efforts that necessity forces upon us. Encouragement can be found in the valuable World War II experiences where these democratic principles were maintained and, also, in the numerous provisions of the new Act (and initial steps thereunder) which declare strongly the intent of Congress to safeguard these principles as part of "the maintenance and furtherance of the American way of life." The principles we have examined here are the keys to a successful defense program.

But our "national defense" program cannot rest upon the idea of military defense alone. In the very exercise of these democratic concepts analyzed herein, it is not enough for individuals to say that this program will prevent communism from spreading. Beyond defense, democratic peoples seek a unifying idea of a free world order, creating in all individuals a greater sense of common purpose. Thus, a fifty year era of development might be possible and be infinitely less costly than a five year era of total war.

and deed, it seems equally important that we work hard on the home front to maintain our country's vigorous democratic character.

We can prevent our country from becoming a "garrison state" in the strict sense of that term-and we can be a true "arsenal of democracy." There is much precedent in strengthening democratic processes even during gigantic military operations affecting our whole economy. For example, in spite of the stress and strain attendant upon the great internecine conflict then raging, President Abraham Lincoln sponsored legislation improving the Court of Claims, saying, "Tt is as much the duty of Government to render prompt justice against itself in favor of citizens as it is to administer the same between private individuals." See Lincoln's Annual Message to Congress, submitted Dec. 3, I86r. 